\title{
QUALITY OF ENFORCEMENT
} AND INVESTMENT DECISIONS. FIRM-LEVEL EVIDENCE FROM SPAIN

Daniel Dejuán and Juans. Mora-Sanguinetti.

Documentos de Trabajo N. 1927

\section{BANCODE ESPAÑA}

\author{
Eurosistema
}

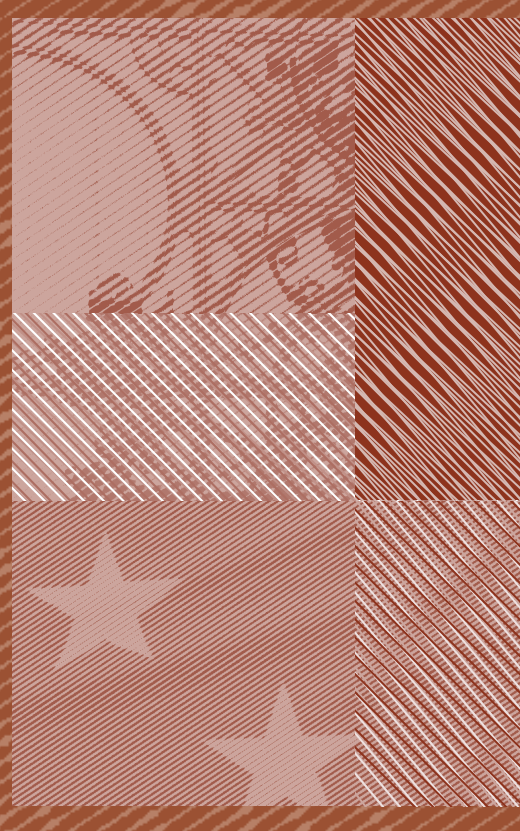


QUALITY OF ENFORCEMENT AND INVESTMENT DECISIONS. FIRM-LEVEL EVIDENCE FROM SPAIN 
QUALITY OF ENFORCEMENT AND INVESTMENT DECISIONS.

FIRM-LEVEL EVIDENCE FROM SPAIN

Daniel Dejuán and Juan S. Mora-Sanguinetti

BANCO DE ESPAÑA

(*) The views expressed are those of the authors and should not be attributed to the Banco de España or the Eurosystem. We are especially grateful to Corinna Ghirelli for her useful comments and for her participation in the first stages of development of this paper. We also thank the participants at the EALE $35^{\text {th }}$ Annual Conference (Università di Milano-Bicocca), the AEDE IX Annual Conference (Universitat de Lleida), the $43^{\text {rd }}$ Simposio of the Spanish Economic Association (SAEe) (Universidad Carlos III de Madrid) and the Research seminar of the Banco de España for their comments and suggestions. Contact: Daniel Dejuán. E-mail: daniel.dejuan@barcelonagse.eu. Juan S. Mora-Sanguinetti. E-mail: juans.mora@bde.es. Tel.: (0034) 913385197. 
The Working Paper Series seeks to disseminate original research in economics and finance. All papers have been anonymously refereed. By publishing these papers, the Banco de España aims to contribute to economic analysis and, in particular, to knowledge of the Spanish economy and its international environment.

The opinions and analyses in the Working Paper Series are the responsibility of the authors and, therefore, do not necessarily coincide with those of the Banco de España or the Eurosystem.

The Banco de España disseminates its main reports and most of its publications via the Internet at the following website: http://www.bde.es.

Reproduction for educational and non-commercial purposes is permitted provided that the source is acknowledged.

C BANCO DE ESPAÑA, Madrid, 2019

ISSN: 1579-8666 (on line) 


\begin{abstract}
Investment decisions are generally irreversible and could be affected by holdup problems and opportunism. Thus, investment may need sound enforcement institutions. This paper analyzes firm level data to identify the impact of judicial system efficacy, as representative of the institutional quality, in business investment decisions. More specifically, this research measures the effects of congestion in the Spanish civil (private) jurisdiction at the local level, both when solving ordinary trials and executions (when a judge forces the debtor to pay or to fulfill an obligation) and finds a negative and significant relationship between judicial inefficacy and the gross investment ratio. The effect holds after running several robustness checks. This paper also analyzes the efficacy of the administrative jurisdiction, inspired by the hypothesis of Acemoglu and Johnson (2005), but it does not have a significant impact on investment in our sample.
\end{abstract}

Keywords: investment decisions, justice, enforcement.

JEL Classification: D25, E22, K41, K12. 


\section{Resumen}

Las decisiones de inversión son generalmente irreversibles y podrían verse afectadas por problemas de cautividad y oportunismo. Un marco de inversión estable necesita, por tanto, de instituciones de ejecución sólidas. Este documento analiza datos a nivel de empresa para estudiar el impacto de la eficacia de funcionamiento del sistema judicial en España, como representativa de la calidad institucional, en las decisiones de inversión empresarial. Más en concreto, esta investigación mide los efectos de la congestión en la jurisdicción civil a nivel local, tanto en los juicios ordinarios como en las ejecuciones (cuando un juez obliga forzosamente al pago de una deuda o al cumplimiento de una obligación), y encuentra una relación negativa y significativa entre la ineficacia judicial y la ratio de inversión bruta. El efecto se mantiene tras realizar diversas pruebas de robustez. Este documento también analiza la eficacia de la jurisdicción administrativa, inspirado por la hipótesis de Acemoglu y Johnson (2005), pero no encuentra que tenga un impacto significativo en la inversión de las empresas de nuestra muestra.

Palabras clave: decisiones de inversión, justicia, ejecución.

Códigos JEL: D25, E22, K41, K12. 


\subsection{Investment and institutional framework}

The literature has analyzed several factors which affect business investment decisions, including financial conditions, companies' profit or uncertainty (ECB, 2016). Together with these factors and potentially in relation to them, investment depends on the institutional framework of the economy. The institutional framework consists of, at least, two ${ }^{1}$ groups of factors: on the one hand, the regulation of markets (the so-called formal institutions), on the other, the quality of enforcement institutions. The first group includes elements as relevant as the labor Law, business insolvency regulations or barriers to entry [see Alesina et al. (2005)]. The second group is made up of institutions which defend the enforceability of contracts, the enforceability of the law and defend companies against unfair expropriations. The most representative example among those "enforcement institutions" is the judicial system. North (1990) defended that among the different institutional characteristics, the differences in the quality of enforcement institutions would be the most relevant among developed and undeveloped economies.

The reason why investment decisions are sensitive to enforcement institutions is because these decisions are generally irreversible and, if they are affected by a certain degree of specificity, they can suffer from holdup problems (Klein et al., 1978, Levchenko, 2007) and opportunism. This is the case of buying a new machine for a factory. Such machine may have been commissioned with a series of adaptations for the particular company. Thus, it may not be useful anymore for another company or may have a lower market value. This generates a problem of dependency for the buyer, but potentially also for the seller (the designer of the machine). A solution to the problem could be drafting a "complete" contract. Alternatively, the parties of a contract could agree to assign the "property rights" over what was not included in the contract to one of them (as a way of "completing" the contract) (Grossman and Hart, 1986). However, contracts are subject to certain risks of non-compliance and, therefore, a stable framework of relationship between enterprises needs mechanisms that may guarantee their execution. For this end there are "enforcement" institutions, whose representative case is the judicial system. That is, the company that considers itself harmed, may resort to denouncing the situation before the relevant court.

Faced with an inefficient institutional framework, i.e. companies consider that they will not be able to defend their interests in the courts in a reasonable time or with the due effectiveness, firms could forego contracting with unknown companies, which is equivalent to a barrier to entry for new providers (Johnson et al., 2002). We could also observe more cases of vertical integration between firms (Klein et al., 1978) or there could be less investment (Nunn, 2007). In the case of vertical integration, companies would prefer obtaining the inputs or the services from an internal provider (what it means to execute the contract internally) than getting them through a contract with an external supplier. ${ }^{2}$

1 To which we should add a third group: that of informal institutions (see, for example, North, 1994), of which there is still little quantitative information at the micro level.

2 We could go a step further and discuss the potential sectoral implications of an ineffective enforcement environment. Following García-Posada and Mora-Sanguinetti (2014), firms which are intensive in physical capital may be less affected by an inefficient system of contract enforcement, since, at least in developed economies, the legal system may be sufficient to protect it (its measurement or control are simpler). On the contrary, the protection of intangible assets (copyright, patents, etc.) is more complex (Kumar et al., 2001). An inefficient contract enforcement environment could lead companies to adopt inefficient technologies (for example, firms may not invest in optimal technologies but in those which minimize dependence on other companies), with detrimental effects on productivity (Palumbo et al., 2013). 
Following the arguments discussed so far, our prediction is that less investment should be observed in economies confronted to less efficient judicial systems (that is, systems that resolve conflicts with greater difficulty).

\subsection{Direct versus "indirect" channels}

The arguments above point to a "direct" effect between judicial inefficacy and investment decisions. That is, a company, confronted with the prospect of not being able to defend its investments, will make more timid (or less risky) investment decisions. Thus, at the aggregate level, there would be less investment.

Nevertheless, this effect could come from "indirect" or intermediate channels, such as the impact of an ineffective judicial system on the credit market. Access to credit may be necessary to finance investments.

Following the literature, higher quality of enforcement institutions is related to more developed credit markets. In other words, the difficulties in accessing credit can be partially explained by the design and functioning of enforcement institutions (La Porta et al. 1997, 1998, Levine 1998; Desai et al. 2005; Ponticelli and Alencar 2016).

The evidence found in the literature is broad. Exploiting variation between countries, Laeven and Majnoni (2005) point out that improvements in judicial enforcement of debt contracts reduce the costs of financial intermediation, Qian and Strahan (2007) and Bae and Goyal (2009) document that better contract enforcement induces credit suppliers to reduce loan spreads, increase loan size and lengthen loan maturity. Djankov et al. (2008) show that reductions in the time required to recover a debt stimulate the development of the debt markets.

On the other hand, if judicial data is specifically used and the impacts within a country are observed (that is, subnational variation), there are also numerous papers pointing to the same effects. Jappelli et al. (2005) found that Italian regions with more efficient judicial systems enjoy greater access to credit. The study by Fabbri and Padula (2004) points in the same direction (for the different Italian judicial districts). In the same vein, we can mention the study of Shvets (2012) for Russia, Visaria (2009) and Chemin (2012) for India and Castelar Pinheiro and Cabral (2009) for Brazil.

However, we are specifically interested in the Spanish case. Mora-Sanguinetti et al. (2017) $)^{3}$ found that higher judicial inefficacy reduces the availability of credit with respect to regional GDP. ${ }^{4}$ The experiment was carried out by linking data at the provincial level of both judicial efficacy and the credit market. This study was already preceded by that of Fabbri (2010), which showed consistent results.

As noted, the effect of justice on credit could be important to understand the enforcement-investment connection because it may be necessary to obtain financing to be able to make an investment. Not surprisingly, credit market conditions are important for firm growth and entrepreneurship (Evans and Jovanovic 1989; Aghion et al. 2007; Beck et al. 2008, Samila and Sorenson 2011) which are a concern in the case of the Spanish economy (see García-Posada and Mora-Sanguinetti, 2014 and 2015).

3 See also this reference for a survey of the literature.

4 This work analyzed the Spanish civil jurisdiction and found evidence that only the efficacy of the execution procedures (and not the declarative procedures) seemed to have significant impacts. 


\subsection{Measuring the impacts of judicial efficacy on firm level investment in Spain}

The gross investment ratio at the firm level shows a high variability in Spain (see section 2.1). Along with this, the performance of the Spanish judicial system shows a high local variability. In other words, the Spanish judicial system could be more effective defending the interests of a damaged company in some provinces with respect to others. As it was argued, these observations may be related because differences in investment among firms may be partially due to differences in the quality of enforcement institutions.

This paper provides an empirical analysis of this research question using Spanish firm level data and exploiting variations in the efficacy of the civil jurisdiction. The Civil jurisdiction deals with private contractual risks (for instance, enterprise to enterprise conflicts). Figure 1 shows the average of the investment ratio and the average of the judicial congestion rate (for civil ordinary judgments) for the period 2002-2016 by Spanish provinces. The regression shows a suggestive negative trend. This simple correlation is thus in line with our working assumption. As is evident, we will validate the assumption with deeper analysis. ${ }^{5}$

\section{Figure 1: Average judicial congestion and investment across Spanish provinces}

(2002-2016)

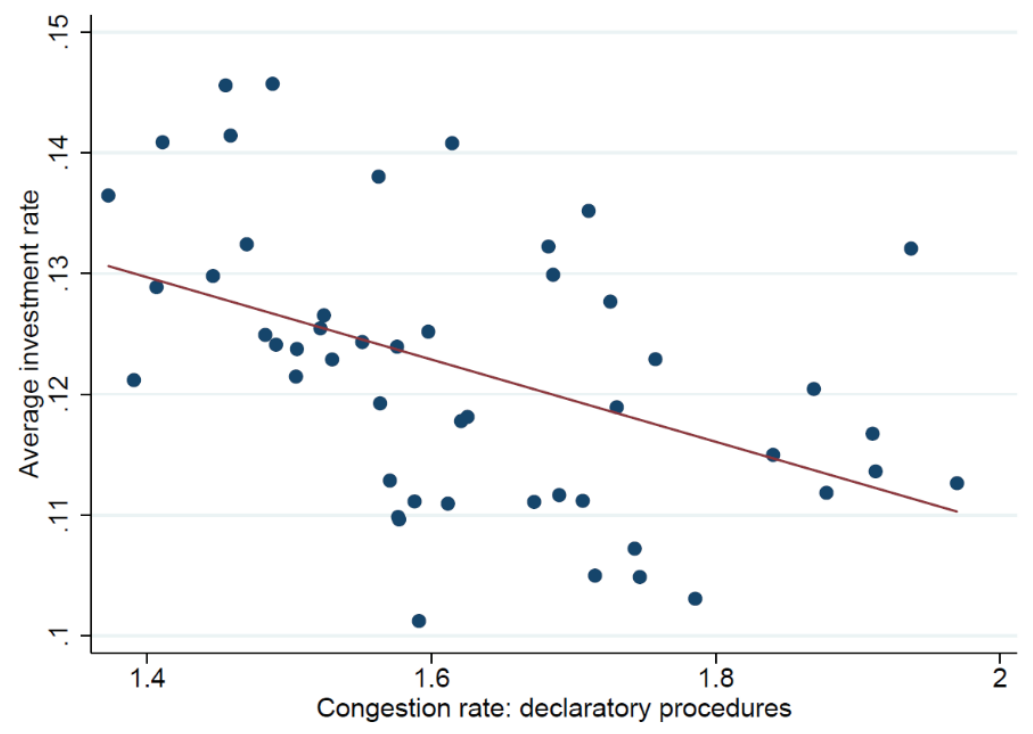

Source: Self elaboration.

The choice of the civil jurisdiction is most suitable for studying the functioning of the contractual channel. Other technical reasons also advise the analysis of that jurisdiction over others (see Section 2.2.). More in general, the study of the effects of the Spanish judicial system, viewed from an aggregate point of view, seems of interest for two reasons: the Spanish justice supports higher litigation rates than those of other developed countries. ${ }^{6}$ Then, perhaps as a result of the first observation (Palumbo et al., 2013), the overall performance of justice is lower than that of many other comparable economies [see data from CEPEJ (2016) or from the OECD (Palumbo et al., 2013) or the approach of the World Bank Doing Business Indicators].

5 For example, we will control the relationship by firm fixed effects, since it could happen that the most congested provinces have a greater concentration of companies in sectors where, on average, investment is lower.

6 Spain would be among the 4 economies of the OECD with higher litigation rates, whether the data is corrected by population or by GDP (in PPP). 
This paper also provides evidence on whether heterogeneous effects of judicial congestion (on investment) can be observed in Spain due to the different degree of vertical integration of companies.

The analysis proposed in this paper is related to two other pieces of research. On the one hand, García-Posada and Mora-Sanguinetti (2015), found that civil judicial efficacy fostered the size and growth of incumbent firms in Spain. Those effects could be related to the impacts of enforcement on investment. On the other hand, Mora-Sanguinetti and Spruk (2018) found that the efficacy of the judicial system could be partially responsible for the pattern of productive specialization of the different Spanish provinces. Judicial efficacy could promote specialization in "complex" economic activities (manufacturing), precisely because it facilitates investment.

The rest of the paper is structured as follows: in section 2 we present how we measure investment at the firm level and how we build our judicial efficacy measures from real judicial data. In section 3 we explain our estimation strategy. Section 4 discusses the results. Section 5 provides a discussion on the heterogeneous effects of judicial congestion based on the different degrees of vertical integration. Finally, section 6 presents some conclusions.

The paper is completed with four appendices. In the first, we show that the results are robust to the exclusion of Madrid and Barcelona. In the Second, we estimate the effects of judicial efficacy using an alternative measure: a litigation rate. In the third, we estimate the impacts of the efficacy of a different jurisdiction (the administrative jurisdiction, dealing with the relations between private enterprises and the public sector). This is inspired by the hypothesis of Acemoglu and Johnson (2005) that put the accent on the risks of expropriation (and not the "contractual" risks). Finally, in the fourth appendix, we provide additional material in the form of graphs and tables. 


\subsection{Investment}

As a measure of investment, we compute the gross investment ratio at the firm level. This is the sum between the gross formation of tangible fixed capital and the gross formation of intangible fixed capital, divided by the sum of the total capital stock. The information comes from the CBI (integrated CBSO, Central de Balances Integrada) of the Banco de España. More specifically, we select firms which are listed in the database at least two years in the period 1997-2016. ${ }^{7}$ Estimates will be mainly made for the period 2002-2016 due to limitations in the enforcement data. ${ }^{8}$ The final sample that we use in the estimates has more than 3 million firms, for which we identify their location. Therefore, we are able to cross them with local judicial efficacy data.

It should be noted that $98 \%$ of firms are small and medium firms. This reflect the composition of Spanish markets. In Appendix A we carry out a robustness test in which we exclude Madrid and Barcelona. These provinces maintain the headquarters of the largest companies. The results of the experiment are confirmed.

Table 1 below shows descriptive statistics for firm level characteristics of the sample we use in the analysis. We observe the financial position of the firm, as measured by the debt rate and debt burden, the profitability as measured by the ROA, and proxies of future growth opportunities (firm level sales growth and employment growth). These are classic firm determinants of corporate investment.

Table 1: Descriptive statistics

\begin{tabular}{lccccc}
\hline \multicolumn{1}{c}{ Variable } & Obs & Mean & Std. Dev. & Min & Max \\
\hline \hline gross investment rate & 3.525 .655 & 0,12 & 0,25 & $-1,61$ & 2,14 \\
gross investment rate in tangibles & 3.525 .655 & 0,11 & 0,25 & $-1,24$ & 1,32 \\
gross investment rate in intangibles & 3.525 .655 & 0,01 & 0,08 & $-0,39$ & 0,93 \\
cash flow & 3.525 .655 & 0,00 & 0,13 & $-0,98$ & 0,92 \\
ROA & 3.525 .655 & 0,04 & 0,17 & $-1,68$ & 0,72 \\
debt burden & 3.525 .655 & 0,60 & 0,98 & 0,00 & 2,77 \\
debt rate & 3.525 .655 & 0,69 & 0,47 & 0,00 & 4,83 \\
sales growth rate & 3.525 .655 & 0,05 & 0,53 & $-1,00$ & 10,29 \\
SME & 3.525 .655 & 0,98 & 0,13 & 0,00 & 1,00 \\
\hline
\end{tabular}

Source: Self elaboration.

\subsection{Measuring judicial efficacy}

In this paper we approximate the efficacy of the functioning of the judicial system computing "congestion rates" (see García-Posada and Mora-Sanguinetti, 2015, among others). These rates are calculated using information on the volume of conflicts accumulated without resolution and the number of resolved conflicts that reach a specific judicial body in a specific jurisdiction. The results are aggregated at the province level (p). A congestion rate could be considered a proxy of the resolution time. The higher the congestion rate, the worse the efficacy of the system (and potentially the higher the length or the cost expected by firms to see their conflicts resolved by the system).

7 This sample has been used in an analysis on the impact of policy uncertainty on firm investment (Dejuan and Ghirelli, 2018). In the description of data and variable definitions we follow closely those reported in that paper.

8 2000-2016 in some estimates. 
More specifically, a congestion rate is calculated as the ratio of the sum of pending cases (measured at the beginning of the year, $t$ ), plus the new cases measured in a specific year divided by the resolved cases in the same year. The data used in this paper is actual data on the functioning of the Spanish judicial system provided by the General Council of the Judiciary (CGPJ) of Spain.

$$
\text { Congestion rate }_{p, t}=\frac{\text { pending } \text { cases }_{p, t-1}+\text { New }_{\text {cases }}, t}{\text { Cases resolved }_{p, t}}
$$

In Appendix B we use an alternative measure of the functioning of the judicial system: a litigation rate. The results are consistent with those presented in the main text.

The judicial system is complex. Therefore, it is necessary to define "where" to measure its efficacy in order to get meaningful information related to firms' investment decisions. As it was argued in Section 1, we aim to identify the jurisdictions related to the protection of companies against contractual risks (private contracting). ${ }^{9}$ As shown in Figure 2, conflicts that reach the Spanish judicial system may be resolved by four different jurisdictions (civil, criminal, labor and administrative). Each jurisdiction has a certain degree of specialization. Threats against the public interest (regulated as crimes in the Penal Code and processed through the Law of Criminal Procedure) are dealt by the Criminal jurisdiction. Labor disputes within a company (for example, related to the dismissal of a worker) are analyzed by the labor jurisdiction. Conflicts between companies related to the enforcement of private contracts are resolved by the civil jurisdiction and conflicts with the public administration are resolved by the contentious-administrative jurisdiction (or "administrative jurisdiction"). It should be noted that in Spain, civil and labor jurisdictions are separated and served by specialized judges (unlike the connections between both jurisdictions that may exist in other countries, such as Italy).

We thus focus on the Civil jurisdiction as this is the jurisdiction most focused on our objective (the study of the effects of uncertainty in private contracting). The nearest jurisdiction would be the labor jurisdiction, but it deals only with some specific types of conflicts (such as dismissals in private companies) and not the generality of matters related to private contracting. Several other reasons, in addition to the specificity of the labor jurisdiction, make us opt for the analysis of civil jurisdiction (see also Mora-Sanguinetti and Garoupa, 2015): in Spain, civil and labor jurisdictions are separate and use different procedural rules. The economic impacts of the civil jurisdiction have been covered much more widely by the literature (both for Spain and internationally) (Palumbo et al., 2013), which guarantees a certain comparability of the results. On the other hand, the civil jurisdiction is much more widely used than the labor jurisdiction in terms of the number of disputes resolved and its procedural rules are considered supplementary to those of other jurisdictions. Finally, the option of integrating the database with civil and labor data does not seem adequate insofar as, as has been said, the procedural regulation of the two jurisdictions is different in Spain. A specific analysis of the impacts of labor jurisdiction on business investment (with its problems and its own channels) will be part of our future research agenda.

9 In the Appendix $\mathrm{C}$ we will deal with the administrative jurisdiction (that is in charge of the protection of companies against expropriation risks). Expropriation risks could not be mitigated by signing a private contract. 
Figure 2: Outline of the Spanish judicial system

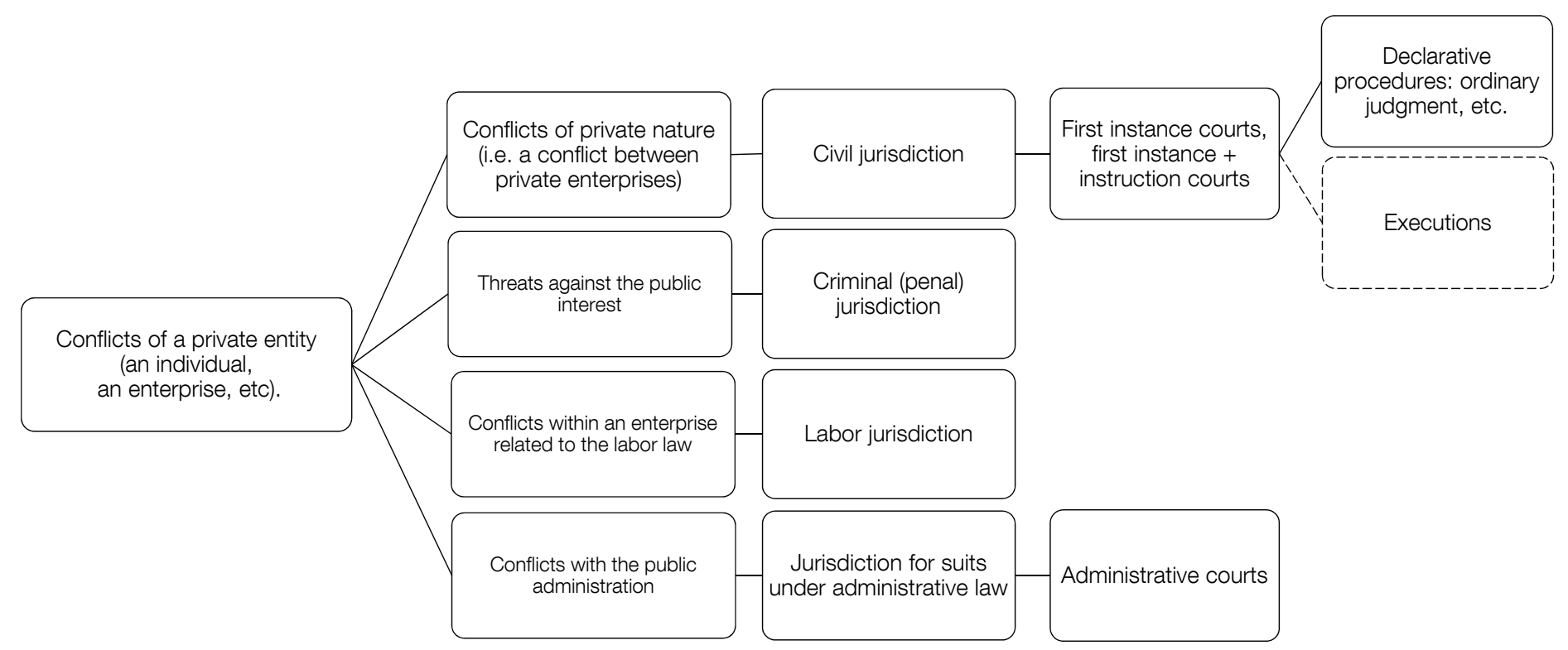

Source: Own elaboration.

As pointed out by the OECD Civil Justice Project (Palumbo et al., 2013), litigation (and therefore the efficacy of justice) can be influenced by the use of Alternative Dispute Resolution mechanisms (ADR) (mediation, arbitration, conciliation). Information on the prevalence of these mechanisms is very scarce because they are managed mainly from the private sector. The OECD was only able to collect (partial) information of its use (\%) to resolve commercial disputes through arbitration and conciliation in 10 countries among which Spain was not available.

As a result, we do not have enough statistical information to incorporate the ADRs into the estimates. However, the reading of the results remains useful insofar as it analyzes the functioning of the judicial system and this is the enforcement mechanism that also covers conflicts related to the ADRs (it is the judicial system which, ultimately, would also resolve a conflict related to the use of the ADRs).

\subsubsection{CIVIL JUSTICE EFFICACY}

More specifically, civil conflicts are those that occur between private companies or citizens, for example, as a result of a misinterpretation of a contract or a breach of an obligation agreed in a contract (for instance, an investment contract). These conflicts are resolved using the specific rules of the Civil Procedure Law. Entry into the system is done through the "courts of first instance" (if the city is large enough) or the "courts of first instance and instruction" (in smaller cities) and take a specific form that, partially, depends on the amount in conflict. Thus, generally, if the conflict has an amount exceeding 6,000 euros, the "ordinary judgment" will be used. ${ }^{10}$ Other types judgments are possible, for instance, the verbal judgment will be used if the amount is equal or below 6,000 euros. All these judgments are classified as "declarative", because the judge will "declare" which company is right and will establish what must be fulfilled.

10 Article 249 of the Civil Procedural Law. 
It may happen that, in spite of the sentence (in the "declarative" judgment), the condemned company (the debtor) decides not to comply with the provisions of the judgment. In this case it would be necessary to return to the court to proceed with the "execution". The judge, in that case, could, for example, forcibly access the accounts of the debtor.

In this paper, we measure the efficacy of the civil jurisdiction, relevant for the resolution of conflicts related to investment contracts between private firms, in these two "stages" (the declaration and the execution). We compute the measures for the whole of the "first instance" and "first instance and instruction" courts of a province. ${ }^{11}$ The congestion rate will be computed annually, for the period 2002-2016. We have begun the measurement of the congestion rate in 2002 because a new Civil Procedural Law (CPL) entered into force in 2001, abrogating the "old" CPL of 1881 . The new CPL changed the types of procedures available and reduced the "formalism"12 (see Mora-Sanguinetti, 2010).

It must be highlighted that the "declarative" civil congestion measure is computed for the whole set of civil conflicts which reach the civil courts, including the different types of contentious procedures and very diverse matters, such as family and "no family" conflicts. This is important because the conflicts related to investment decisions do not have preference to be judged in the Spanish courts. Therefore, an enterprise is affected by the congestion of the civil jurisdiction in general (as a result of business conflicts but also family conflicts) and will make its decisions accordingly. ${ }^{13}$

Figure 3 shows the time variation of the congestion rate in the civil jurisdiction (when solving a "declarative" judgment) for the whole economy (as a simple average across provinces over time): on average, the congestion rate was higher during the economic crisis and we only observe a slight reduction in the last observation (2016) already in the expansion period. This suggests that inefficacy in the Spanish judicial system may be countercyclical. Already, Ginsburg and Hoetker (2006) and Palumbo et al. (2013) found international evidence in this regard. Mora-Sanguinetti et al. (2017) discussed the Spanish case. This countercyclicality could result from companies having more problems to fulfill their contracts in a crisis context, so that the courts' workload could be higher. However, important differences can be observed among regions, as will be discussed later.

Figure 4 below shows the time variation of province congestion rates averaged across specific regions (Comunidades Autónomas): the three most populated regions (Andalusia, in the south, Catalonia, containing Barcelona, and Madrid) and the Basque Country (in the north). Such disaggregation reveals differential patterns across regions. While Andalusia and Madrid display a spike in the average congestion rate in 2009, the evolution of this series for Catalonia and the Basque country seems less sensitive to the business cycle. In addition, the congestion rate in the Basque country (which is known to be below the average) steadily increases since 2010 while the congestion rate in Catalonia is rather decreasing since 2008, although with an uneven pattern. In our analysis we exploit both time variation and across-province variation to identify the average effect of the congestion rate on the gross investment to capital ratio.

11 No separate information is available for Ceuta or for Melilla.

12 In the sense of Djankov et al. (2003).

13 Although it is not technically correct, we have computed an estimation test including only the "ordinary" conflicts arriving to the Civil courts and excluding family conflicts. Therefore, we have run the estimation selecting only a set of conflicts that will more likely contain "investment" conflicts. The results are similar to those shown in this paper. The correlation between the two civil measures is in fact 0.8 . 
Figure 3: Congestion rate in the civil jurisdiction (ordinary judgments) over time

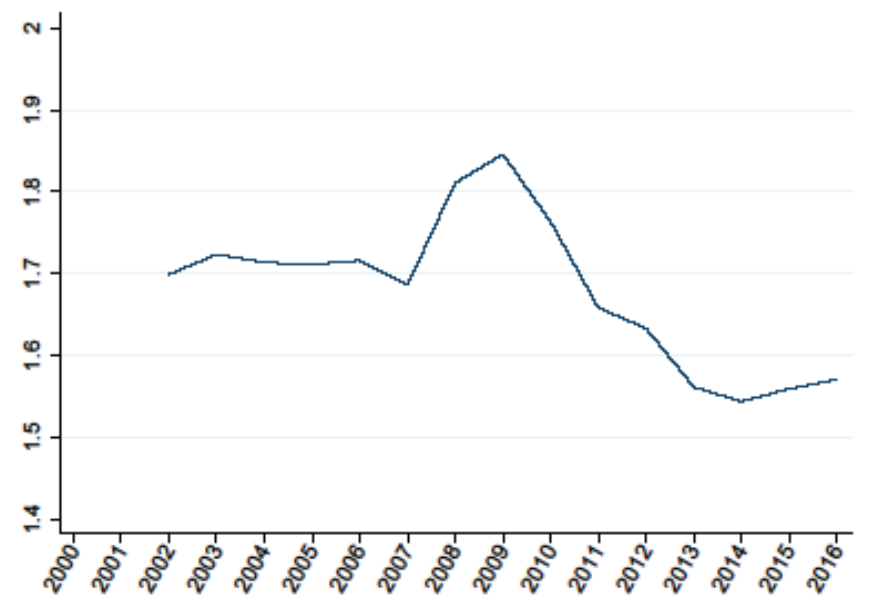

Source: Own elaboration from CGPJ data.

Figure 4: Evolution of the congestion rate (ordinary judgments) for some regions

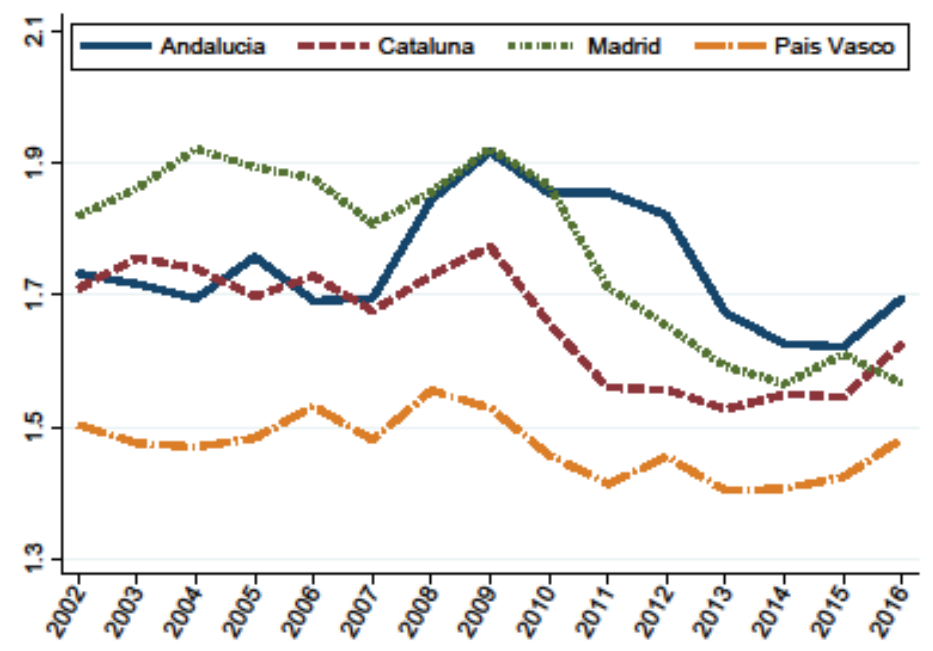

Source: Own elaboration from CGPJ data.

Figure 5 and 6 show a lower level of disaggregation (the provincial level), which is the one used in the estimates. Figure 5 shows the time-average of the congestion rate for each province. This gives an idea of the across-province variation of the index. Spain shows a high variability in the efficacy of justice at the provincial level. Consistent with figure 4, the provinces belonging to Andalusia, Catalonia and Madrid show a relatively darker color than many other areas. In general, all the Mediterranean provinces and Madrid (which concentrate the bulk of the Spanish population) show worse behavior. Figure 6 shows instead the standard deviation of the congestion rate computed over the period for each province. This shows the time-variation of the index: the time variation of the index is greater the darker the color of the province. 
Figure 5: Average (2002-2016) congestion rate (ordinary judgments) across provinces in Spain
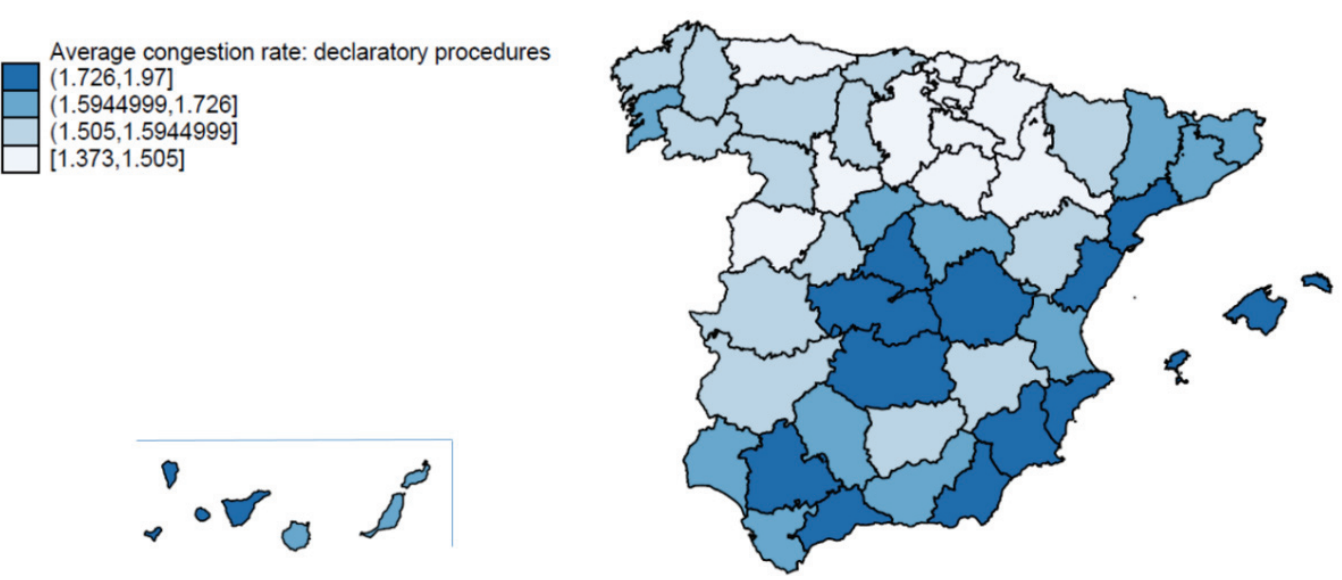

Source: Own elaboration from CGPJ data.

Figure 6: Time variation (2002-2016) of the congestion rate (ordinary judgments) for each province in Spain
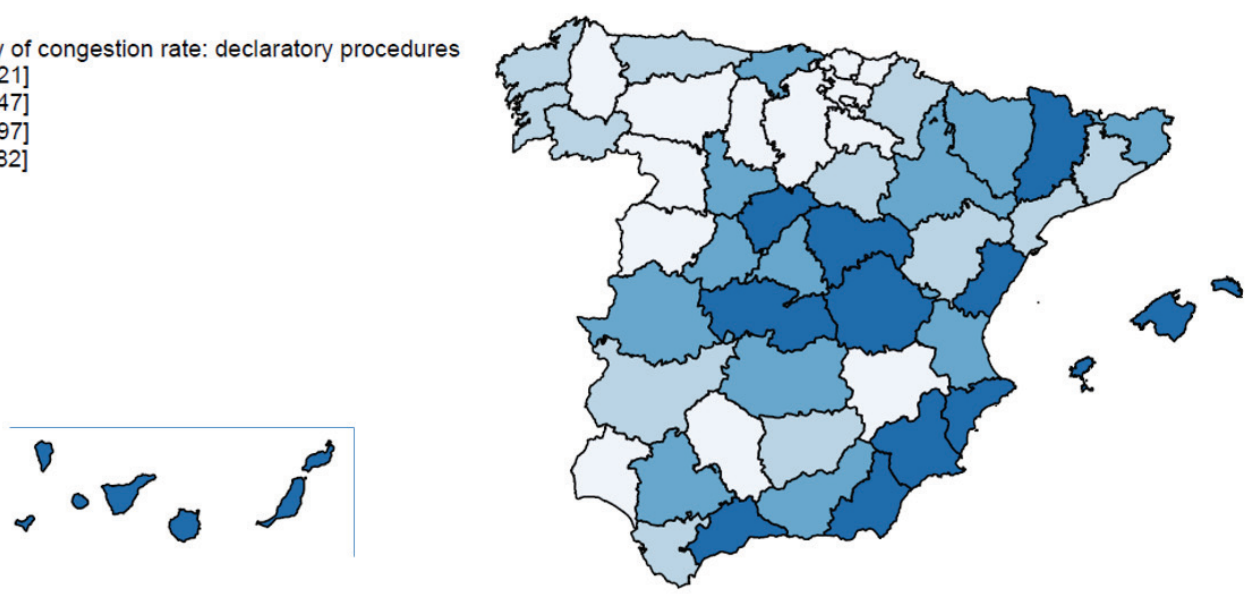

Source: Own elaboration from CGPJ data. 


\section{Estimation strategy}

To estimate the effect of judicial efficacy on corporate investment, we rely on a firm fixed-effects model where we regress gross investment to capital ratio on relevant time-varying firm characteristics and a measure of civil judicial efficacy that varies over time and across provinces, controlling for time (year) fixed effects. Our strategy consists in augmenting a classical investment equation with our judicial efficacy proxy measured at the province level to explicitly test the effect that congestion may have on firm investment decisions. Proper identification entails several challenges which we next discuss in detail.

We estimate the following equation at the firm level (i), for the period (year, t) $(t=2003-2016)^{14}$ through a linear model including fixed effects at the firm (i) level $\left(\alpha_{i}\right)$, time (year) $\left(d_{t}\right)$ and province $\left(d_{p}\right)$ :

$$
I / K_{i, p, t}=\alpha_{i}+\beta_{1} X_{i, p, t-1}+\beta_{2} C_{p, t-1}+\beta_{3} M_{p, t-1}+d_{t}+\varepsilon_{i, p, t}
$$

The dependent variable $\left(I / K_{i, p, t}\right)$ is the gross investment ratio, which is defined as gross fixed capital formation over total capital stock. $C_{t, p}$ is the congestion rate of the civil jurisdiction (in one of the two stages: ordinary judgments or executions inside the civil jurisdiction) and $X$ is a vector that contains firm level characteristics. Finally, $M$ refers to time varying province specific controls while $\varepsilon_{i, p, t}$ is the error term, which we cluster at the firm and at the year level in order to allow for serial correlation and cross-sectional correlation (Petersen, 2009). To minimize endogeneity concerns regarding plausible reverse causality between the realized investment rate and both firm's characteristics and external determinants, we lag all explanatory variables by one year. The working hypothesis, as it was explained in section 1 , is that the judicial efficacy faced by firms in year $t$ affect investment decisions in $t+1$.

The fixed effects model allows to control for all time-invariant characteristics that may determine investment: for instance, differences in business practices across companies, cultural differences or differences in the economic or demographic structure of provinces that are time-invariant in the period considered. Along with them, time fixed effects control for all aggregate variables that change over time but not across firms: for instance, macroeconomic conditions, national policies or special events that may affect corporate investment.

Following the existing literature, we explicitly control for firm time-varying variables that may affect investment, such as the profitability of a firm and its financial position. ${ }^{15}$ The former control is introduced in order to alleviate the omission of the firm's investment opportunities, which is an unobservable determinant. Despite many authors rely on the use of the Tobin's q measure, the nature of our data (with a high proportion of SMEs) implies considering alternative proxies for investment opportunities. Namely, we control for the return on assets and sales growth. On the other hand, we control for the financial position of the firm which may also influence investment decisions through the credit channel. We control for the debt to asset ratio, the debt burden and cash-flows.

14 The information about congestion was obtained for the first time in 2002. But since we use a lag, the period remains at $\mathrm{t}=2003-2016$.

15 Notice that, while the profile of a specific firm and its decisions may not cause congestion, as long as a correlation exists, their omission would contaminate the estimation of the effect of judicial efficacy on investment. The main channel through which firm's characteristics may be correlated with judicial congestion is through economic conditions. After the introduction of time fixed effects, we would not expect that the omission of firm characteristics would significantly affect the estimation of the congestion rate. 
Our regressor of interest is the measure of judicial efficacy which varies across provinces and over time. Since we control for time fixed effects, we control for any aggregate time varying factor that affects all the cross-section. This would absorb our measure of judicial system efficacy if the latter was measured at the national level. We can still identify the effect of our measure of judicial efficacy because it varies over time and across-provinces. Hence, to estimate the effect of the congestion rate on corporate investment we exploit the time variation of judicial efficacy within each province and across provinces.

Our identification challenge is threefold. First, notice that judicial congestion is measured at the province level. Since we want to estimate the effect that a higher congestion rate may have on firms' investment decisions, mobility of firms across provinces to resolve conflicts would virtually kill our identification. Arguably, firms would litigate their conflicts in those provinces where the judicial system works more efficiently. In other words, as it was discussed by Mora-Sanguinetti et al. (2017), a possible source of concern for the validity of the analysis could be that conflicts of companies located in a province "p" could be solved in any other province "no p". Fortunately, this is limited by Law: the CPL (Articles 50 and 51) establishes that the competent court to resolve a conflict will be, by default, that of the domicile of the defendant, both in the case of natural and legal persons. We must recognize, however, that there are exceptions to these rules: the Law allows the parties to agree to choose another place to resolve a conflict (Article 55) and there is also a certain choice for the plaintiff while can also sue a businessman (defendant) in the place where he does business (in disputes arising from his business or professional activity). These exceptions should not be a relevant problem for our estimates as we observe that the provinces are an important "frontier" to economic activity in Spain: workers tend to move only within the province limits (Jimeno et al. 2015). According to the Labor Force Survey, workers commuting to a province other than their province of residence amounted to $4.6 \%$ during the period 2005-2013. On the other hand, firms changing province amount to just around $0.1 \%$ each year. Finally, as discussed in García-Posada and Mora-Sanguinetti (2015), a large majority of companies in Spain are small and most of their trade and relations with other companies are likely to occur within one province. ${ }^{16}$

Another threat to our identification strategy is the possibility of reverse causality so that judicial efficacy would be endogenous to the economic structure, and in particular to firms' investment plans. While we argued that judicial efficacy may have an impact on investment (see Section 1), we cannot sustain that investment decisions (and the conflicts derived from them) influence in a remarkable way the measures of judicial efficacy we compute. This is due to the Spanish judicial structure. We construct our measures of efficacy based on the performance of first instance (and first instance and instruction) courts (on the side of the civil jurisdiction). None of these judicial bodies are specialized in investment decisions nor deal exclusively with business disputes. The mentioned civil courts resolve, in addition to conflicts arising from an investment decision, other cases such as evictions or inheritance conflicts (see García-Posada and Mora-Sanguinetti, 2015). Therefore, an increase in litigation related to investment decisions could only be transferred to congestion rates indirectly. The creation of non-specialized courts could, in addition, be based on factors much broader than the litigation derived from investment decisions.

Last but not least, our estimation could be biased due to the fact that the congestion rate is expected to be counter-cyclical and the economic cycle clearly affects firms' investment

16 As an additional argument, if all firms could move to the most efficient provinces, this would increase local congestion rates. In equilibrium, congestion rates would be the same across all provinces. This is not what it is observed in the data. 
opportunities and expected demand, which are relevant investment determinants. Periods of high economic growth will be associated with good firm's performance and a lower probability of breach of contract while the opposite may occur in periods of recession. Thus, not controlling for the business cycle would introduce an omitted variable bias in our estimation. We alleviate this concern by explicitly controlling for the business cycle in two main ways. First, we introduce time fixed effects so that we are controlling for everything that may vary along time such as the national business cycle and the credit cycle. Second, we additionally introduce different variables at the province and region (Comunidad Autónoma) level in order to control for time varying factors that may vary differently across provinces. In particular, we control for the province business-cycle (GDP growth), the province evolution of total credit over GDP (as well as delinquent credit over GDP) and the population growth. The next section discusses the results. 


\section{Results}

As it was discussed, we will consider two potentially relevant proxies for the congestion rate according to "where" we measure the efficacy of the judicial system: we will look at the congestion rate at the declarative stage (congestion declarative) and at the execution stage (congestion execution) in the civil jurisdiction. According to the channels described in section 1 , we expect to observe a negative effect of a higher congestion rate on investment. This relationship was naively captured in Figure 1 at the province level. Our empirical exercise will allow us to establish a causal claim on such relationship by controlling for other firm-specific and aggregate determinants of investment and to investigate potential heterogeneous effects.

Table 2 presents our baseline results for the case of the judicial congestion rate at the declaration stage. In all regressions, we control for firm specific unobservable heterogeneity, time fixed effects and firm specific controls. In column 1 we can see the results when we estimate a classic investment model. Proxies of economic performance such as the return on assets and the growth of sales have a positive effect on the investment rate. Together with this, a higher debt to asset ratio and debt burden, which proxy the financial position of a firm, appear to negatively affect the level of investment while the cash to asset ratio has a positive effect on investment. Both findings are consistent with the role of financial frictions in the access to credit and investment.

Column 2 of Table 2 extends the classical investment model by including a measure of judicial congestion. Classical investment determinants remain significant and affecting the investment rate in the expected direction. The judicial congestion rate measured at the declaration stage has a negative effect on the investment rate, even after controlling for firm specific characteristics and time fixed effects. Controlling for aggregate shocks ensures that our estimators are not contaminated by the impact that the business cycle may have both on the investment rate and judicial congestion. In particular, we find that a 10-percentage point decrease in the congestion rate would increase on average the investment rate by roughly 0.1 percentage points, caeteris paribus. In order to have a better sense of the relevance of this magnitude an example may be helpful. In year 2010, Alicante was one of the provinces with higher levels of judicial congestion (220 unresolved cases per 100 resolved ones), while Alava exhibited one of the lowest level of congestion (140 unresolved cases per 100 resolved ones). If Alicante had the judicial efficacy observed in Alava, investment in Alicante would increase by $\Delta$ Congestion Rate $\times \beta 2=80 \mathrm{pp}^{*} 0.01=0.8 \mathrm{pp}$, which is a magnitude similar to the effect that a $10 \mathrm{pp}$ increase in cash flows has on average on the level of investment.

This result is robust to the inclusion of controls at the province and region (Comunidad Autónoma) level. We first control for the number of lawyers in each province. This variable may be related to litigation [as suggested by Mora-Sanguinetti and Garoupa, (2015)]. No significant effect is found for this variable. In column 3 we additionally control for province population growth, which also appears to be non-significant. Finally, in columns 4 to 7 , we further control for the local business cycle. In the case there is variation among regions in terms of their economic performance, the local business cycle could be potentially correlated with both the congestion measure and firms' local investment decisions. Both credit to GDP ratio and regional GDP growth are significant and have a positive effect on investment. In particular, a $10 \mathrm{pp}$ increase in local GDP growth implies a $2 \mathrm{pp}$ increase in the investment ratio, which is a relevant magnitude. Notably, once we control for the local business cycle, the effect of congestion rate remains significant although smaller in magnitude. Hence, while the evolution of congestion may be correlated with the economic performance of each 
province, the estimated effect on investment does not disappear once we control for aggregate and local economic shocks. All in all, our estimation suggests that even if judicial efficacy is less relevant than classical determinants or the business cycle in explaining investment, improving the judicial system efficacy as measured by a lower congestion rate at the declarative stage would still have a non-negligible effect on investment.

Table 3 considers the effect of judicial congestion when we focus on the execution stage. Recall that this stage is only reached when, after the "declarative" judgment, the condemned company decides not to comply with the provisions of the judgment and it is necessary to return to the court to proceed with the "execution". Following the same structure of Table 2, we first introduce our measure of judicial congestion while only controlling for firm specific variables and we then control for regional specific trends. In all specifications we find a significant negative effect of judicial congestion on the investment rate. Namely, a 10-percentage point decrease in the congestion rate (which would for example entail a change from 120 unresolved cases per 100 resolved ones to 110 unresolved per 100 resolved ones) increases, on average, the investment rate by roughly 0.01 percentage points, caeteris paribus.

Notice that, while the direction of the effect is the same in both the declarative and the execution stage, we find significant differences in terms of the magnitude of the estimate. In particular, the impact of congestion on investment at the declarative stage is ten times bigger than the effect observed at the execution stage. Arguably, the lower relevance of congestion at the execution stage could be related with the fact that less firms do actually reach this second stage and thus the overall sensitivity to judicial efficacy is lower.

Table 2: Effects of the efficacy of the civil jurisdiction (when solving declarative judgments) on investment

\begin{tabular}{|c|c|c|c|c|c|c|c|}
\hline & (1) & (2) & (3) & (4) & (5) & (6) & (7) \\
\hline Cash flow & $\begin{array}{c}0.0669 * * * \\
(0.0033)\end{array}$ & $\begin{array}{c}0.0669 * * * \\
(0.0033)\end{array}$ & $\begin{array}{c}0.0669 * * * \\
(0.0033)\end{array}$ & $\begin{array}{c}0.0669 * * * \\
(0.0033)\end{array}$ & $\begin{array}{c}0.0669 * * * \\
(0.0033)\end{array}$ & $\begin{array}{c}0.0669 * * * \\
(0.0033)\end{array}$ & $\begin{array}{c}0.0669 * * * \\
(0.0033)\end{array}$ \\
\hline ROA & $\begin{array}{c}0.0235 * * * \\
(0.0047)\end{array}$ & $\begin{array}{c}0.0235^{* * *} \\
(0.0047)\end{array}$ & $\begin{array}{c}0.0235^{* * *} \\
(0.0047)\end{array}$ & $\begin{array}{c}0.0235^{* * *} \\
(0.0047)\end{array}$ & $\begin{array}{c}0.0235 * * * \\
(0.0047)\end{array}$ & $\begin{array}{c}0.0235^{* * *} \\
(0.0047)\end{array}$ & $\begin{array}{c}0.0235^{* * *} \\
(0.0047)\end{array}$ \\
\hline Debt burden & $\begin{array}{c}-0.0086 * * * \\
(0.0003)\end{array}$ & $\begin{array}{c}-0.0086 * * * \\
(0.0003)\end{array}$ & $\begin{array}{c}-0.0086 * * * \\
(0.0003)\end{array}$ & $\begin{array}{c}-0.0086^{* * *} \\
(0.0003)\end{array}$ & $\begin{array}{c}-0.0086 * * * \\
(0.0003)\end{array}$ & $\begin{array}{c}-0.0086 * * * \\
(0.0003)\end{array}$ & $\begin{array}{c}-0.0086^{* * *} \\
(0.0003)\end{array}$ \\
\hline Debt rate & $\begin{array}{c}-0.0317^{* * *} \\
(0.0028)\end{array}$ & $\begin{array}{c}-0.0317^{* * *} \\
(0.0028)\end{array}$ & $\begin{array}{c}-0.0317^{* * *} \\
(0.0028)\end{array}$ & $\begin{array}{c}-0.0317^{* * *} \\
(0.0028)\end{array}$ & $\begin{array}{c}-0.0317^{* * *} \\
(0.0028)\end{array}$ & $\begin{array}{c}-0.0317^{* * *} \\
(0.0028)\end{array}$ & $\begin{array}{c}-0.0317^{* * *} \\
(0.0028)\end{array}$ \\
\hline Sales growth & $\begin{array}{c}0.0093^{* * *} \\
(0.0008)\end{array}$ & $\begin{array}{c}0.0093 * * * \\
(0.0008)\end{array}$ & $\begin{array}{c}0.0093^{* * *} \\
(0.0008)\end{array}$ & $\begin{array}{c}0.0093^{* * *} \\
(0.0008)\end{array}$ & $\begin{array}{c}0.0093 * * * \\
(0.0008)\end{array}$ & $\begin{array}{c}0.0093^{* * *} \\
(0.0008)\end{array}$ & $\begin{array}{c}0.0093^{* * *} \\
(0.0008)\end{array}$ \\
\hline Congestion declarative & & $\begin{array}{c}-0.0142 * * * \\
(0.0029)\end{array}$ & $\begin{array}{c}-0.0141 * * * \\
(0.0029)\end{array}$ & $\begin{array}{c}-0.0140 * * * \\
(0.0030)\end{array}$ & $\begin{array}{c}-0.0112 * * * \\
(0.0030)\end{array}$ & $\begin{array}{c}-0.0098 * * * \\
(0.0028)\end{array}$ & $\begin{array}{c}-0.0085^{* * *} \\
(0.0023)\end{array}$ \\
\hline Numbero of Lawyers & & & $\begin{array}{l}-16.0270 \\
(10.1354)\end{array}$ & $\begin{array}{l}-15.9884 \\
(10.0891)\end{array}$ & $\begin{array}{c}-15.4596 \\
(9.2780)\end{array}$ & $\begin{array}{c}-14.5111 \\
(8.6338)\end{array}$ & $\begin{array}{l}-13.8371 \\
(8.2696)\end{array}$ \\
\hline Regional pop. Growth & & & & $\begin{array}{l}-0.0148 \\
(0.0717)\end{array}$ & $\begin{array}{c}0.0138 \\
(0.0746)\end{array}$ & $\begin{array}{l}-0.0029 \\
(0.0766)\end{array}$ & $\begin{array}{l}-0.0115 \\
(0.0758)\end{array}$ \\
\hline Regional Credit/GDP & & & & & $\begin{array}{c}0.0130 * * * \\
(0.0035)\end{array}$ & $\begin{array}{c}0.0126 * * * \\
(0.0035)\end{array}$ & $\begin{array}{l}0.0112 * * \\
(0.0038)\end{array}$ \\
\hline Regional GDP growth & & & & & & $\begin{array}{l}0.0702 * * \\
(0.0252)\end{array}$ & \\
\hline CCAA GDP growth & & & & & & & $\begin{array}{c}0.2165^{* * *} \\
(0.0552)\end{array}$ \\
\hline Time FE & YES & YES & YES & YES & YES & YES & YES \\
\hline Observations & $3,513,160$ & $3,513,160$ & $3,513,160$ & $3,513,160$ & $3,513,160$ & $3,513,160$ & $3,513,160$ \\
\hline R-squared & 0.3154 & 0.3155 & 0.3155 & 0.3155 & 0.3155 & 0.3155 & 0.3155 \\
\hline
\end{tabular}

Robust standard errors in parentheses

$* * * \mathrm{p}<0.01,{ }^{* *} \mathrm{p}<0.05,{ }^{*} \mathrm{p}<0.1$

Source: Self elaboration. 
Table 3: Effects of the efficacy of civil executions on investment

\begin{tabular}{|c|c|c|c|c|c|c|}
\hline & $(2)$ & (3) & (4) & (5) & (6) & (7) \\
\hline Cash flow & $\begin{array}{c}0.0669 * * * \\
(0.0033)\end{array}$ & $\begin{array}{c}0.0669 * * * \\
(0.0033)\end{array}$ & $\begin{array}{c}0.0669 * * * \\
(0.0033)\end{array}$ & $\begin{array}{c}0.0669 * * * \\
(0.0033)\end{array}$ & $\begin{array}{c}0.0669 * * * \\
(0.0033)\end{array}$ & $\begin{array}{c}0.0669 * * * \\
(0.0033)\end{array}$ \\
\hline ROA & $\begin{array}{c}0.0235^{* * *} \\
(0.0047)\end{array}$ & $\begin{array}{c}0.0235^{* * *} \\
(0.0047)\end{array}$ & $\begin{array}{c}0.0235^{* * *} \\
(0.0047)\end{array}$ & $\begin{array}{c}0.0235^{* * *} \\
(0.0047)\end{array}$ & $\begin{array}{c}0.0235^{* * *} \\
(0.0047)\end{array}$ & $\begin{array}{c}0.0235^{* * *} \\
(0.0047)\end{array}$ \\
\hline Debt burden & $\begin{array}{c}-0.0086 * * * \\
(0.0003)\end{array}$ & $\begin{array}{c}-0.0086 * * * \\
(0.0003)\end{array}$ & $\begin{array}{c}-0.0086^{* * *} \\
(0.0003)\end{array}$ & $\begin{array}{c}-0.0086^{* * *} \\
(0.0003)\end{array}$ & $\begin{array}{c}-0.0086^{* * *} \\
(0.0003)\end{array}$ & $\begin{array}{c}-0.0086 * * * \\
(0.0003)\end{array}$ \\
\hline Debt rate & $\begin{array}{c}-0.0317^{* * *} \\
(0.0028)\end{array}$ & $\begin{array}{c}-0.0317^{* * *} \\
(0.0028)\end{array}$ & $\begin{array}{c}-0.0317^{* * *} \\
(0.0028)\end{array}$ & $\begin{array}{c}-0.0317^{* * *} \\
(0.0028)\end{array}$ & $\begin{array}{c}-0.0317^{* * *} \\
(0.0028)\end{array}$ & $\begin{array}{c}-0.0317^{* * *} \\
(0.0028)\end{array}$ \\
\hline Sales growth & $\begin{array}{c}0.0093^{* * *} \\
(0.0008)\end{array}$ & $\begin{array}{c}0.0093^{* * *} \\
(0.0008)\end{array}$ & $\begin{array}{c}0.0093^{* * *} \\
(0.0008)\end{array}$ & $\begin{array}{c}0.0093^{* * *} \\
(0.0008)\end{array}$ & $\begin{array}{c}0.0093^{* * *} \\
(0.0008)\end{array}$ & $\begin{array}{c}0.0093^{* * *} \\
(0.0008)\end{array}$ \\
\hline Congestion execution & $\begin{array}{c}-0.0020 * * * \\
(0.0005)\end{array}$ & $\begin{array}{c}-0.0020 * * * \\
(0.0005)\end{array}$ & $\begin{array}{c}-0.0020 * * * \\
(0.0005)\end{array}$ & $\begin{array}{c}-0.0016 * * * \\
(0.0005)\end{array}$ & $\begin{array}{c}-0.0015^{* * *} \\
(0.0004)\end{array}$ & $\begin{array}{c}-0.0012 * * * \\
(0.0004)\end{array}$ \\
\hline Numbero of Lawyers & & $\begin{array}{l}-19.3806^{*} \\
(10.7603)\end{array}$ & $\begin{array}{c}-19.2683^{*} \\
(10.6822)\end{array}$ & $\begin{array}{c}-18.0864 * \\
(9.6426)\end{array}$ & $\begin{array}{c}-16.7755^{*} \\
(8.6820)\end{array}$ & $\begin{array}{c}-15.8536 * \\
(8.5157)\end{array}$ \\
\hline Regional pop. Growth & & & $\begin{array}{l}-0.0352 \\
(0.0751)\end{array}$ & $\begin{array}{l}-0.0028 \\
(0.0780)\end{array}$ & $\begin{array}{l}-0.0182 \\
(0.0786)\end{array}$ & $\begin{array}{l}-0.0234 \\
(0.0782)\end{array}$ \\
\hline Regional Credit/GDP & & & & $\begin{array}{c}0.0129 * * * \\
(0.0034)\end{array}$ & $\begin{array}{c}0.0124^{* * *} \\
(0.0035)\end{array}$ & $\begin{array}{l}0.0112^{* *} \\
(0.0038)\end{array}$ \\
\hline Regional GDP growth & & & & & $\begin{array}{c}0.0717^{* * *} \\
(0.0238)\end{array}$ & \\
\hline CCAA GDP growth & & & & & & $\begin{array}{c}0.2148^{* * *} \\
(0.0546)\end{array}$ \\
\hline Time FE & YES & YES & YES & YES & YES & YES \\
\hline Observations & $3,513,160$ & $3,513,160$ & $3,513,160$ & $3,513,160$ & $3,513,160$ & $3,513,160$ \\
\hline R-squared & 0.3155 & 0.3155 & 0.3155 & 0.3155 & 0.3155 & 0.3155 \\
\hline
\end{tabular}

Source: Self elaboration.

Our sample allows as to explore potential differential effects of judicial congestion along the business cycle. While the channel through which congestion rate affects corporate investment may be present no matter external economic conditions, it could be the case that its relevance is amplified during periods of higher economic uncertainty and financial distress. As long as during periods of recessions firms acknowledge higher contractual risks, their investment decisions should be more sensitive to judicial efficacy. We test for the possibility of differential effects over time by interacting the two congestion measures with dummies constructed for the period of economic boom (2004-2007), the Great Recession (2008-2013) and the economic recovery (2014-2016).

Table 4 below shows the results for both the congestion rate when measured at the declarative stage (Column 1) and at the execution stage (Column 2). In both specifications we are controlling for classical investment determinants, variables measured at the province level, time fixed effect and firm fixed effects. We find that the effect of judicial congestion appears to be non-significant for the years previous to the Great Recession, characterized by sustained and high economic growth. However, both during the economic crisis and the first years of recovery, higher levels of congestion have a significant negative impact on the investment decision of firms. A 10 pp decrease in our measure implies $0.2 \mathrm{pp}$ increase in investment during the period of economic crisis while the effect increases to 0.3 during the period of economic recovery. This pattern hints that the role played by judicial efficacy in shaping firms' investment decisions has varied over time, being more relevant during periods of higher economic uncertainty and higher contractual risks. 
Column 2 of Table 4 shows the results for the case of judicial congestion when measured at the execution stage. Similar results are observed. We find that the effect of congestion is not significant during the years before the Great Recession. Afterwards, it becomes negative and significant but of smaller magnitude to what we found for the case of the congestion rate when measured at the declarative stage.

Table 4: Effect of congestion along the business cycle

\begin{tabular}{|c|c|c|}
\hline & $(1)$ & $(2)$ \\
\hline Congestion declarative & $\begin{array}{c}0.0152 \\
(0.0087)\end{array}$ & \\
\hline Congestion declarative $x$ (period 2008-2013) & $\begin{array}{c}-0.0266 * * * \\
(0.0074)\end{array}$ & \\
\hline Congestion declarative $x$ (period 2014-2016) & $\begin{array}{c}-0.0352 * * * \\
(0.0078)\end{array}$ & \\
\hline Congestion execution & & $\begin{array}{c}0.0014 \\
(0.0009)\end{array}$ \\
\hline Congestion execution $x$ (period 2008-2013) & & $\begin{array}{c}-0.0033^{* * *} \\
(0.0007)\end{array}$ \\
\hline Congestion execution x (period 2014-2016) & & $\begin{array}{c}-0.0039 * * * \\
(0.0009)\end{array}$ \\
\hline Time FE & YES & YES \\
\hline Firm controls & YES & YES \\
\hline Regional controls & YES & YES \\
\hline Observations & $3,358,614$ & $3,358,614$ \\
\hline R-squared & 0.3205 & 0.3205 \\
\hline
\end{tabular}

Robust standard errors in parentheses

*** $\mathrm{p}<0.01,{ }^{* *} \mathrm{p}<0.05,{ }^{*} \mathrm{p}<0.1$ 


\section{$5 \quad$ Heterogeneous effects}

As a result of higher judicial inefficacy, it may be argued that we could observe more cases of vertical integration between firms (Klein et al., 1978). This means that firms would prefer obtaining the inputs (or the services) from an internal provider than getting them through a contract with an external supplier. In the case of an "internal" problem, the firm could just ignore the judicial system and enforce the internal agreement by its own means. In other words, highly vertically integrated firms may be less harmed by judicial inefficacy (Johnson et al. 2002).

This section aims to test if investment decisions of vertically integrated are less affected by judicial congestion. In order to do so, we first construct a variable ("Dependency") to capture how much does a firm use intermediate inputs with respect to its creation of valueadded. The variable "intermediate inputs" proxy external purchases. The information is obtained, as before, from the CBI (Banco de España).

The variable is defined as:

$$
\text { dependency }=\frac{\text { Intermediate } \text { inputs }_{t-1}}{\text { Value Added } d_{t-1}}
$$

To test the hypothesis, we have created a set of dummies which refer to different levels of dependence of intermediate inputs (as a proxy for vertical integration). In particular, we look at those firms with a dependency rate below the 25 and 50 percentiles of the distribution. Then, those dummies are interacted with the congestion rate to look for heterogenous effects (Dummy25 in the specification below).

$$
\begin{aligned}
\frac{I}{K}_{i, p, t}= & \alpha_{i}+\beta_{1} X_{i, p, t-1}+\beta_{21} C_{p, t-1}+\beta_{22} C_{p, t-1} \times \text { Dummy } 25_{i, p, t .1}+\beta_{3} M_{p, t-1} \\
& +d_{t}+\varepsilon_{i, p, t}
\end{aligned}
$$

Results are presented in Tables 6 and suggest that no differential effects can be found when analyzing the declarative stage (for which we were finding larger overall effects of congestion). Therefore, in that case, the effect of vertical integration suggested by the literature would not be present in our sample. However, conversely, we find an effect at the execution stage: those firms that are less dependent on intermediate inputs are less affected by the congestion rate. 
Table 5: Heterogeneous effects (declarative and execution stage)

\begin{tabular}{|c|c|c|}
\hline & $(1)$ & $(2)$ \\
\hline Congestion declarative & $\begin{array}{c}-0.0104 * * * \\
(0.0026)\end{array}$ & $\begin{array}{c}-0.0077^{* *} \\
(0.0029)\end{array}$ \\
\hline Congestion declarative $x$ Dependency $\mathrm{p}[0-25]$ & $\begin{array}{c}0.0017 \\
(0.0047)\end{array}$ & \\
\hline Congestion declarative $x$ Dependency $p[0-50]$ & & $\begin{array}{l}-0.0043 \\
(0.0032)\end{array}$ \\
\hline Congestion execution & $\begin{array}{c}-0.0021^{* * *} \\
(0.0005)\end{array}$ & $\begin{array}{c}-0.0018^{* * *} \\
(0.0006)\end{array}$ \\
\hline Congestion execution x Dependency $p[0,25]$ & $\begin{array}{c}0.0026 * * * \\
(0.0006)\end{array}$ & \\
\hline Congestion execution $x$ Dependency $p[0,50]$ & & $\begin{array}{c}0.0007 \\
(0.0004)\end{array}$ \\
\hline Time FE & YES & YES \\
\hline Firm controls & YES & YES \\
\hline Regional controls & YES & YES \\
\hline Observations & $3,305,041$ & $3,305,041$ \\
\hline R-squared & 0.3143 & 0.3145 \\
\hline
\end{tabular}

Robust standard errors in parentheses

*** $\mathrm{p}<0.01, * * \mathrm{p}<0.05, * \mathrm{p}<0.1$

Source: Self elaboration. 


\section{Conclusions}

Investment depends on the institutional framework of the economy. Among other factors, the institutional matrix includes the institutions that defend the enforceability of contracts, the enforceability of the law and defend companies against unfair expropriations. The reason why investment decisions could be sensitive to enforcement institutions is because these decisions are generally irreversible and, if they are affected by a certain degree of specificity, they can suffer from holdup problems and opportunism. Thus, a stable framework of relationship between enterprises needs mechanisms that may guarantee their execution.

At the empirical level, we observe that the gross investment ratio at the firm level shows a high variability in Spain. Along with this, the performance of the Spanish judicial system shows a high local variability. These observations may be related (among other factors) following the above mentioned arguments. This paper provides an empirical analysis of this potential relationship. More specifically, we compute the gross investment ratio at the firm level (for around 3 million enterprises), but also many other variables capturing the financial "health" of the firms such as the debt burden. Then, we also construct a judicial congestion rate for the Spanish civil jurisdiction at the local level, both at the "declarative" and the "execution" stages.

To estimate the effect of judicial efficacy on corporate investment, we rely on a firm fixed-effects model. We include fixed effects at the firm level, time (year) and province. The estimation (at the declaration stage) confirms that the classical investment determinants appear to be significant and stable, affecting the investment rate in the expected direction. The judicial congestion rate has a negative effect on the investment rate, even after controlling for firm specific characteristics and aggregate variables which could be potentially correlated with both the congestion rate and investment decisions. More specifically, a 10 percentage point decrease in the congestion rate would increase, on average, the investment rate by roughly 0.1 percentage points, caeteris paribus. The effect, however, does not seem to be constant over time. While the impact of congestion is not significant during the years previous to the Great Recession, it becomes negative and significant afterwards. This suggest that the sensitivity of investment decisions to judicial inefficacy may depend on the stage of the business cycle: periods of recession with higher contractual risks may amplify the effect of judicial congestion.

In a separate piece, this research also studies the relationship between higher judicial inefficacy and the degree of vertical integration between firms. Following the literature, highly vertically integrated firms may be less harmed by judicial inefficacy. We test specifically if investment decisions of vertically integrated are less affected by judicial congestion. We find an effect at the execution stage: those firms that are less dependent on intermediate inputs are less affected by the congestion rate. 


\section{References}

ACEMOGLU, D., and S. JOHNSON (2005). "Unbundling Institutions". Journal of Political Economy 113(5). 949-995.

AGHION, P., T. FALLY and S. SCARPETTA (2007). Credit constraints as a barrier to the entry and post-entry growth of firms. Economic Policy, 22, 731-779.

ALESINA, A., S. ARDAGNA, G. NICOLETTI and F. SCHIANTARELLI (2005). "Regulation and Investment". Journal of the European Economic Association 3(4). 791-825.

BAE, K. H., and V. K. GOYAL (2009). Creditor rights, enforcement, and bank loans. Journal of Finance, 64(2), 823-860.

BECK, T., A. DEMIRGUC-KUNT, L. LAEVEN and R. LEVINE (2008). Finance, firm size, and growth. Journal of Money, Credit and Banking, 40(7), 1379-1405.

CASTELAR PINHEIRO, A., and C. CABRAL (1999). Credit markets in Brazil: The role of judicial enforcement and other institutions. Red de Centros de Investigación de la Oficina del Economista Jefe, Banco Interamericano de Desarrollo, Documento de Trabajo R-368.

CEPEJ - European Commission for the Efficiency of Justice (2016). European judicial systems. Efficiency and quality of justice. Edition 2016 (2014 data). CEPEJ STUDIES No. 23.

CHEMIN, M. (2012). Does court speed shape economic activity? Evidence from a court reform in India. Journal of Law Economics and Organization, 28(3), 460-485.

DEJUAN, D., and C. GHIRELLI (2018). "Determinants of firms' policy investment in Spain: the role of policy uncertainty". Mimeo.

DESAI, M., P. GOMPERS and J. LERNER (2005). Institutions, capital constraints and entrepreneurial firm dynamics: Evidence from Europe. Harvard NOM working paper No. 03-59.

DJANKOV, S., O. HART, C. MCLIESH and A. SHLEIFER (2008). Debt enforcement around the world. Journal of Political Economy, 116(6), 1105-1149.

DJANKOV, S., R. LA PORTA, F. LÓPEZ-DE-SILANES and A. SHLEIFER (2003). "Courts". The Quarterly Journal of Economics 118. 453-517.

EUROPEAN CENTRAL BANK (ECB) (2016). "Business investment developments in the euro area since the crisis". ECB Publications, 31 October.

EVANS, D. S., and B. JOVANOVIC (1989). An estimated model of entrepreneurial choice under liquidity constraints. Journal of Political Economy, 97(4), 808-827.

FABBRI, D., (2010). Law enforcement and firm financing: Theory and evidence. Journal of the European Economic Association, 8(4), 776-816.

FABBRI, D., and M. PADULA (2004). Does poor legal enforcement make households credit-constrained? Journal of Banking \& Finance, 28(10), 2369-2397.

GARCÍA-POSADA, M., and J. S. MORA-SANGUINETTI (2014). "Entrepreneurship and Enforcement Institutions: Disaggregated Evidence for Spain" European Journal of Law and Economics 40 (1). 49-74.

GARCÍA-POSADA, M., and J. S. MORA-SANGUINETTI (2015). "Does (average) size matter? Court enforcement, business demography and firm growth". Small Business Economics 44 (3), 639-669.

GINSBURG, T., and G. HOETKER (2006). The unreluctant litigant? An empirical analysis of Japan's turn to litigation. Journal of Legal Studies, 35, 31-59.

GROSSMAN, S. J., and O. D. HART (1986). "The costs and Benefits of Ownership: A Theory of Vertical and Lateral Integration". Journal of Political Economy 94 (2). 691-719.

JAPPELLI, T., M. PAGANO and M. BIANCO (2005). Courts and banks: effects of judicial enforcement on credit markets. Journal of Money Credit and Banking, 37, 224-244.

JIMENO, J. F., M. MARTíNEZ-MATUTE and J. S. MORA-SANGUINETTI (2015). "Employment Protection Legislation and Labor Courts' Activity in Spain". Working Paper 1507 Banco de España.

JOHNSON, S., J. MCMILLAN and C. WOODRUFF (2002). "Courts and relational contracts". Journal of Law Economics \& Organization, 18 (1). 221-277.

KLEIN, B., R. CRAWFORD and A. ALCHIAN (1978). "Vertical Integration, Appropriable Rents, and the Competitive Contracting Process", Journal of Law \& Economics 21 (2). 297-326.

KUMAR, K., R. RAJAN and L. ZINGALES (2001). "What Determines Firm Size?”. Chicago Booth Working Paper.

LA PORTA, R., F. LÓPEZ DE SILANES, A. SCHLEIFER and R. W. VISHNY (1997). Legal determinants of external finance. Journal of Finance, 52, 1131-1150.

LA PORTA, R., F. LÓPEZ DE SILANES, A. SCHLEIFER and R. W. VISHNY (1998). Law and finance. Journal of Political Economy, 106, 1113-1155.

LAEVEN, L., and G. MAJNONI (2005). Does judicial efficiency lower the cost of credit? Journal of Banking \& Finance, 29(7), 1791-1812.

LEVCHENKO, A. A. (2007). "Institutional Quality and International Trade". The Review of Economic Studies 74 (3). 791-819.

LEVINE, R. (1998). The legal environment, banks, and long-run economic growth. Journal of Money, Credit and Banking, 30(3), 596-613.

MORA-SANGUINETTI, J. S. (2010). "A Characterisation of the Judicial System in Spain: Analysis with Formalism Indices". Economic Analysis of Law Review 1 (2): 210-240.

MORA-SANGUINETTI, J. S., and N. GAROUPA (2015) "Do lawyers induce litigation? Evidence from Spain, 2001-2010". International Review of Law and Economics 44. 29-41.

MORA-SANGUINETTI, J. S., M. MARTÍNEZ-MATUTE and M. GARCÍA-POSADA (2017). "Credit, crisis and contract enforcement: evidence for the Spanish loan market". European Journal of Law and Economics 44 (2), 361-383.

MORA-SANGUINETTI, J. S., and R. SPRUK (2018). "Industry vs services: do enforcement institutions matter for specialization patterns? Disaggregated evidence from Spain". Working Paper 1812 Banco de España. 
NORTH, D. C. (1990). Institutions, institutional change and economic performance. Cambridge University Press, Cambridge.

NORTH, D. C. (1994). Economic performance through time. The American Economic Review 84. pp. 359-368.

NUNN, N. (2007). "Relationship-Specificity, Incomplete Contracts and the Pattern of Trade". The Quarterly Journal of Economics 122 (2). 569-600.

PALUMBO, G., G. GIUPPONI, L. NUNZIATA and J. S. MORA-SANGUINETTI (2013). "The Economics of Civil Justice: New Cross-Country Data and Empirics". OECD Economics Department Working Papers No. 1060

PETERSEN, M. A. (2008). "Estimating Standard Errors in Finance Panel Data Sets: Comparing Approaches". The Review of Financial Studies, 22(1) pp. 435-480.

PONTICELLI, J., and L. ALENCAR (2016). Court enforcement, bank loans and firm investment: Evidence from a bankruptcy reform in Brazil. The Quarterly Journal of Economics, 131(3), 1365-1413.

QIAN, J., and P. STRAHAN (2007). How law and institutions shape financial contracts: The case of bank loans. Journal of Finance, 62(6), 2803-2834.

SAMILA, S., and O. SORENSON (2011). Venture capital, entrepreneurship, and economic growth. The Review of Economics and Statistics, 93(1), 338-349.

SHVETS, J. (2013). Judicial institutions and firms' external finance: Evidence from Russia. Journal of Law Economics and Organization, 29(4), 735-764.

THE EUROPEAN LAWYER 100 (2013). http://www.thelawyer.com/analysis/intelligence/european-100/

VISARIA, S. (2009). Legal reform and loan repayment: The microeconomic impact of debt recovery tribunals in India American Economic Journal: Applied Economics, 1(3), 59-81. 


\section{Appendix A. Robustness check when Madrid and Barcelona are excluded}

The results of the estimates for the effects of the efficacy of the civil jurisdiction (when solving declarative judgments) on investment are confirmed when we exclude the provinces of Madrid and Barcelona from the estimates.

There are a number of reasons why Madrid and Barcelona could affect the overall results: first, these are the provinces with higher level of economic activity in Spain. Second, the biggest law firms are concentrated there. Third, also the main banks have been traditionally located in Madrid and Barcelona (the financial sector has been very much litigious during the crisis in Spain).

Table A.1. Effects on investment when Madrid and Barcelona are excluded

\begin{tabular}{|c|c|c|c|c|c|c|}
\hline & (1) & $(2)$ & (3) & (4) & (5) & (6) \\
\hline Cash flow & $\begin{array}{c}0.0681^{* * *} \\
(0.0033)\end{array}$ & $\begin{array}{c}0.0681^{* * *} \\
(0.0033)\end{array}$ & $\begin{array}{c}0.0681^{* * *} \\
(0.0033)\end{array}$ & $\begin{array}{c}0.0681^{* * *} \\
(0.0033)\end{array}$ & $\begin{array}{c}0.0681^{* * *} \\
(0.0033)\end{array}$ & $\begin{array}{c}0.0681^{* * *} \\
(0.0033)\end{array}$ \\
\hline ROA & $\begin{array}{c}0.0273^{* * *} \\
(0.0051)\end{array}$ & $\begin{array}{c}0.0273 * * * \\
(0.0051)\end{array}$ & $\begin{array}{c}0.0273^{* * *} \\
(0.0051)\end{array}$ & $\begin{array}{c}0.0273^{* * *} \\
(0.0051)\end{array}$ & $\begin{array}{c}0.0272 * * * \\
(0.0051)\end{array}$ & $\begin{array}{c}0.0272 * * * \\
(0.0051)\end{array}$ \\
\hline Debt burden & $\begin{array}{c}-0.0080 * * * \\
(0.0003)\end{array}$ & $\begin{array}{c}-0.0080 * * * \\
(0.0003)\end{array}$ & $\begin{array}{c}-0.0080 * * * \\
(0.0003)\end{array}$ & $\begin{array}{c}-0.0080 * * * \\
(0.0003)\end{array}$ & $\begin{array}{c}-0.0080 * * * \\
(0.0003)\end{array}$ & $\begin{array}{c}-0.0080^{* * *} \\
(0.0003)\end{array}$ \\
\hline Debt rate & $\begin{array}{c}-0.0329 * * * \\
(0.0034)\end{array}$ & $\begin{array}{c}-0.0328^{* * *} \\
(0.0034)\end{array}$ & $\begin{array}{c}-0.0328 * * * \\
(0.0034)\end{array}$ & $\begin{array}{c}-0.0328^{* * *} \\
(0.0034)\end{array}$ & $\begin{array}{c}-0.0328 * * * \\
(0.0034)\end{array}$ & $\begin{array}{c}-0.0328 * * * \\
(0.0034)\end{array}$ \\
\hline Sales growth & $\begin{array}{c}0.0092^{* * *} \\
(0.0009)\end{array}$ & $\begin{array}{c}0.0092^{* * *} \\
(0.0009)\end{array}$ & $\begin{array}{c}0.0092^{* * *} \\
(0.0009)\end{array}$ & $\begin{array}{c}0.0092^{* * *} \\
(0.0009)\end{array}$ & $\begin{array}{c}0.0092^{* * *} \\
(0.0009)\end{array}$ & $\begin{array}{c}0.0092^{* * *} \\
(0.0009)\end{array}$ \\
\hline Congestion declarative & $\begin{array}{c}-0.0110 * * * \\
(0.0025)\end{array}$ & $\begin{array}{c}-0.0108^{* * *} \\
(0.0025)\end{array}$ & $\begin{array}{c}-0.0108 * * * \\
(0.0026)\end{array}$ & $\begin{array}{c}-0.0108 * * * \\
(0.0025)\end{array}$ & $\begin{array}{c}-0.0097^{* * *} \\
(0.0025)\end{array}$ & $\begin{array}{c}-0.0077^{* * *} \\
(0.0025)\end{array}$ \\
\hline Number of Lawyers & & $\begin{array}{l}-28.0903 * \\
(13.9903)\end{array}$ & $\begin{array}{c}-28.0907^{*} \\
(13.9929)\end{array}$ & $\begin{array}{l}-28.7260 * \\
(14.5267)\end{array}$ & $\begin{array}{l}-27.5023^{*} \\
(13.1490)\end{array}$ & $\begin{array}{l}-25.2868^{*} \\
(12.7241)\end{array}$ \\
\hline Regional pop. Growth & & & $\begin{array}{l}-0.0002 \\
(0.0726)\end{array}$ & $\begin{array}{l}-0.0137 \\
(0.0724)\end{array}$ & $\begin{array}{l}-0.0251 \\
(0.0743)\end{array}$ & $\begin{array}{l}-0.0281 \\
(0.0736)\end{array}$ \\
\hline Regional Credit/GDP & & & & $\begin{array}{l}-0.0087 \\
(0.0056)\end{array}$ & $\begin{array}{l}-0.0076 \\
(0.0054)\end{array}$ & $\begin{array}{l}-0.0057 \\
(0.0050)\end{array}$ \\
\hline Regional GDP growth & & & & & $\begin{array}{c}0.0509 * * \\
(0.0210)\end{array}$ & \\
\hline CCAA GDP growth & & & & & & $\begin{array}{c}0.2114^{* * *} \\
(0.0529)\end{array}$ \\
\hline Time FE & YES & YES & YES & YES & YES & YES \\
\hline Observations & $2,464,401$ & $2,464,401$ & $2,464,401$ & $2,464,401$ & $2,464,401$ & $2,464,401$ \\
\hline R-squared & 0.3105 & 0.3105 & 0.3105 & 0.3105 & 0.3105 & 0.3105 \\
\hline
\end{tabular}

Robust standard errors in parentheses

$* * * p<0.01, * * p<0.05, * p<0.1$

Source: Self elaboration. 


\section{Appendix B. Effects of the litigation rate on investment}

In this Appendix we measure the impact of a litigation rate (as an alternative to the congestion rate explained in section 2.2) on investment decisions.

The litigation rate is defined as the number of new conflicts that have reached the judicial system in a year $t$ (and province, $p$ ) divided by the population of the province in that year. We calculate the rate for the new cases which enter the declarative stage in the Civil jurisdiction.

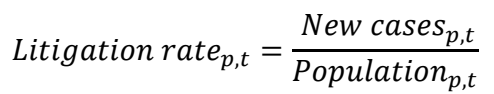

This measure is of interest, while the literature reminds us that litigation is very significantly related to judicial slowness (Palumbo et al., 2013). Therefore this rate could be considered a predictor of judicial efficacy. Also, as already indicated in Section 1.3. Spain is a country characterized by a very high civil litigation rate, above most of the OECD economies.

Table B.1. Effects of the litigation rate on investment

\begin{tabular}{|c|c|c|c|c|c|c|}
\hline & (1) & (2) & (3) & (4) & (5) & (6) \\
\hline Litigation rate & $\begin{array}{c}-0.8412 * * * \\
(0.1543)\end{array}$ & $\begin{array}{c}-0.8448 * * * \\
(0.1548)\end{array}$ & $\begin{array}{c}-0.8897 * * * \\
(0.1604)\end{array}$ & $\begin{array}{c}-0.8810 * * * \\
(0.1808)\end{array}$ & $\begin{array}{c}-0.8173 * * * \\
(0.1660)\end{array}$ & $\begin{array}{c}-\mathbf{0 . 7 0 3 1 * * *} \\
(0.1374)\end{array}$ \\
\hline Number of Lawyers & & $\begin{array}{l}-21.9132 * \\
(11.8290)\end{array}$ & $\begin{array}{l}-21.7238^{*} \\
(11.6368)\end{array}$ & $\begin{array}{l}-20.3436 * \\
(10.9427)\end{array}$ & $\begin{array}{l}-19.0765 * \\
(10.0939)\end{array}$ & $\begin{array}{c}-17.9529 * \\
(9.6100)\end{array}$ \\
\hline Regional pop. Growth & & & $\begin{array}{c}-0.0991 \\
(0.0696)\end{array}$ & $\begin{array}{l}-0.0654 \\
(0.0714)\end{array}$ & $\begin{array}{l}-0.0739 \\
(0.0718)\end{array}$ & $\begin{array}{l}-0.0711 \\
(0.0723)\end{array}$ \\
\hline Regional Credit/GDP & & & & $\begin{array}{c}0.0142^{* * *} \\
(0.0033)\end{array}$ & $\begin{array}{c}0.0137^{* * *} \\
(0.0034)\end{array}$ & $\begin{array}{c}0.0124^{* * *} \\
(0.0038)\end{array}$ \\
\hline Regional GDP growth & & & & & $\begin{array}{c}0.0604 * * \\
(0.0231)\end{array}$ & \\
\hline CCAA GDP growth & & & & & & $\begin{array}{c}0.1859 * * * \\
(0.0525)\end{array}$ \\
\hline Time FE & YES & YES & YES & YES & YES & YES \\
\hline Firm Controls & YES & YES & YES & YES & YES & YES \\
\hline Observations & $3,513,160$ & $3,513,160$ & $3,513,160$ & $3,513,160$ & $3,513,160$ & $3,513,160$ \\
\hline R-squared & 0.3155 & 0.3155 & 0.3155 & 0.3155 & 0.3155 & 0.3155 \\
\hline
\end{tabular}

Robust standard errors in parentheses

$* * * p<0.01, * * p<0.05, * p<0.1$

Source: Self elaboration.

Table B.1 presents the effect of the litigation rate on investment when controlling for firm specific characteristics, regional controls, firm fixed effects and time fixed effects. We observe that an increase in the litigation rate has a negative impact on investment. In particular, a $1 \mathrm{pp}$ increase in the litigation rate entails a decrease of investment by $0.8 \mathrm{pp}$. 


\section{Appendix C. Testing the hypothesis of Acemoglu and Johnson (2005)}

In parallel to the channel explained in the previous sections (what we could call the "contractual" risks channel), investment may also be sensitive to a risk which does not depend on contracts between private parties: the risk of expropriation by politicians and elites (Acemoglu and Johnson, 2005). According to Acemoglu and Johnson (2005), institutions related to the defense of property rights would have a significant effect on investment, while institutions related to better contracting would have a much more limited impact. More specifically, countries with greater restrictions on their politicians and elites and greater protection against expropriation on their part would enjoy higher investment rates. Moreover, at the country level, the quality of "contract" institutions would have no effect on the investment to GDP ratio if the relationship is controlled by the quality of institutions which defend the property rights.

It is difficult to think of a significant case of "classic" expropriation in Spain today (that is, the unjustified and direct expropriation of private assets by the public administration). However, we could think of alternative forms of "expropriation" that could still take place nowadays: such as the favoritism of the government towards some business groups or, in general, the making of non-neutral public decisions that could affect investment. Firms harmed by these problems could resort to the help of the judicial system (so that it invalidates the decisions of the public administration).

The analysis of the "expropriation" channel must be approached with a different judicial database. Expropriation risks by the public sector are dealt by the administrative jurisdiction. More specifically, that jurisdiction controls the decisions of the public administrations and it would resolve a conflict between a private company and the local, regional or national administrations (unlike the civil jurisdiction, which resolves conflicts between private companies or citizens). The procedural rules that govern this jurisdiction are different and, therefore, we can extend the years for which we compute the measure of congestion to 2000-2016. The congestion measure in this jurisdiction is based on the workload of the administrative courts (juzgados contencioso-administrativos).

As before, we estimate an equation at the firm level ( () , for the period (year, $t$ ) $(t=2000-2016)$ through a linear model including fixed effects at the firm $(i)$ level $\left(\alpha_{i}\right)$, time (year) $\left(d_{t}\right)$ and province $\left(d_{p}\right)$ :

$$
I / K_{i, p, t}=\alpha_{i}+\beta_{1} X_{i, p, t-1}+\beta_{2} C_{p, t-1}+\beta_{3} M_{p, t-1}+d_{t}+\varepsilon_{i, p, t}
$$

Regarding the discussion on reverse causality (in parallel with what was mentioned in the case of civil courts), the administrative courts are not specialized in investment decisions nor deal exclusively with business disputes as they also solve immigration (extranjería) or electoral conflicts, among others. Therefore, an increase in litigation related to investment decisions could only be transferred to congestion rates indirectly.

Table B.1. shows the effects of the efficacy of the administrative jurisdiction on investment. The effect is negative, but only weakly significant in some of the estimations. 
Table C.1.: Effects of the efficacy of the administrative jurisdiction on investment

\begin{tabular}{|c|c|c|c|c|c|c|}
\hline & (1) & (2) & (3) & (4) & (5) & (6) \\
\hline \multirow[t]{2}{*}{ Congestion administrative } & -0.0001 & -0.0002 & -0.0003 & $-0.0013^{*}$ & $-0.0013^{*}$ & -0.0011 \\
\hline & $(0.0009)$ & (0.0009) & $(0.0009)$ & $(0.0006)$ & $(0.0007)$ & $(0.0010)$ \\
\hline \multirow[t]{2}{*}{ Number of Lawyers } & & $-19.7979 *$ & $-19.7776 *$ & $-19.3506^{*}$ & $-17.9126^{* *}$ & $-16.8044^{*}$ \\
\hline & & $(10.8817)$ & $(10.8277)$ & (9.1111) & (8.0511) & $(7.9513)$ \\
\hline \multirow[t]{2}{*}{ Regional pop. Growth } & & & -0.0250 & 0.0017 & -0.0153 & -0.0224 \\
\hline & & & $(0.0808)$ & $(0.0820)$ & $(0.0834)$ & $(0.0823)$ \\
\hline \multirow[t]{2}{*}{ Regional Credit/GDP } & & & & $0.0149 * * *$ & $0.0142^{* * *}$ & $0.0126 * * *$ \\
\hline & & & & $(0.0033)$ & $(0.0034)$ & $(0.0038)$ \\
\hline \multirow[t]{2}{*}{ Regional GDP growth } & & & & & $0.0754 * *$ & \\
\hline & & & & & $(0.0251)$ & \\
\hline \multirow[t]{2}{*}{ CCAA GDP growth } & & & & & & $0.2254 * * *$ \\
\hline & & & & & & $(0.0556)$ \\
\hline Time FE & YES & YES & YES & YES & YES & YES \\
\hline Firm Controls & YES & YES & YES & YES & YES & YES \\
\hline Observations & $3,513,160$ & $3,513,160$ & $3,513,160$ & $3,513,160$ & $3,513,160$ & $3,513,160$ \\
\hline R-squared & 0.3154 & 0.3154 & 0.3154 & 0.3155 & 0.3155 & 0.3155 \\
\hline
\end{tabular}

Robust standard errors in parentheses

*** $p<0.01,{ }^{* *} p<0.05,{ }^{*} p<0.1$

Source: Self elaboration.

Table C.2. shows the effects of the efficacy in the administrative jurisdiction when also the efficacy of the civil jurisdiction is considered. This experiment seems nearer to the one proposed by Acemoglu and Johnson (2005). As before, no significant results are found.

Table C.2.: Effects of the efficacy of the administrative jurisdiction on investment when civil justice efficacy is also considered

\begin{tabular}{lcccccc}
\hline & $(1)$ & $(2)$ & $(3)$ & $(4)$ & $(5)$ & $(6)$ \\
\hline \hline & & & & & & \\
Congestion administrative & -0.0001 & -0.0001 & -0.0002 & $-0.0011^{*}$ & -0.0011 & -0.0010 \\
& $(0.0008)$ & $(0.0008)$ & $(0.0008)$ & $(0.0006)$ & $(0.0007)$ & $(0.0010)$ \\
Congestion declarative & $-0.0142^{* * *}$ & $-0.0141^{* * *}$ & $-0.0140^{* * *}$ & $-0.0110^{* * *}$ & $-0.0096^{* * *}$ & $-0.0084^{* * *}$ \\
& $(0.0029)$ & $(0.0029)$ & $(0.0030)$ & $(0.0030)$ & $(0.0028)$ & $(0.0023)$ \\
Rlawyers_1 & & -16.1606 & -16.1566 & $-16.5450^{*}$ & $-15.5666^{*}$ & $-14.7829^{*}$ \\
& & $(10.4075)$ & $(10.3736)$ & $(9.1814)$ & $(8.4421)$ & $(8.1004)$ \\
pobgr_1 & & & -0.0161 & 0.0062 & -0.0102 & -0.0179 \\
& & & $(0.0731)$ & $(0.0758)$ & $(0.0786)$ & $(0.0783)$ \\
Rcredito_tot_1 & & & & $0.0135 * * *$ & $0.0131^{* * *}$ & $0.0116^{* * *}$ \\
& & & & $(0.0035)$ & $(0.0035)$ & $(0.0038)$ \\
pibtotgr_1 & & & & & $0.0701^{* *}$ & $(0.0253)$ \\
& & & & & & $0.2158^{* * *}$ \\
pibtotgr_CCAA_1 & & & & & & $(0.0551)$ \\
& & & & & & \\
\hline Time FE & & & & & & \\
Firm Controls & YES & YES & YES & YES & YES & YES \\
Observations & $3,513,160$ & $3,513,160$ & $3,513,160$ & $3,513,160$ & $3,513,160$ & $3,513,160$ \\
R-squared & 0.3155 & 0.3155 & 0.3155 & 0.3155 & 0.3155 & 0.3155 \\
\hline \hline
\end{tabular}

Robust standard errors in parentheses

${ }^{* * *} p<0.01,{ }^{* *} p<0.05,{ }^{*} p<0.1$

Source: Self elaboration. 


\section{Appendix D. Additional figures.}

Figure D.1.: Evolution of the congestion rate (civil executions) for some regions

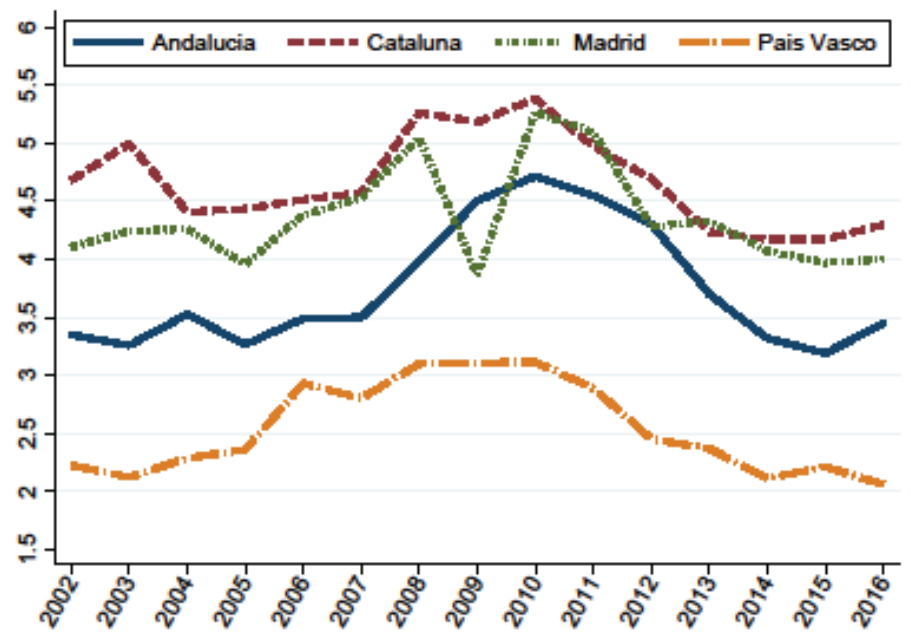

Source: Own elaboration from CGPJ data.

Figure D.2.: Evolution of the congestion rate (administrative jurisdiction) for some regions

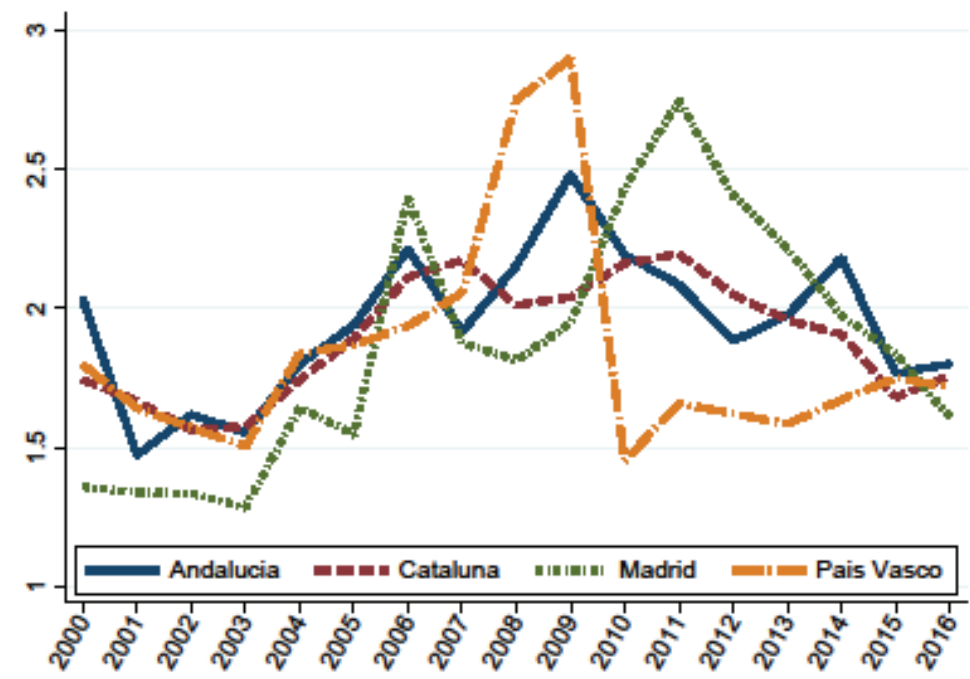

Source: Own elaboration from CGPJ data. 
Table D.1: Aggregate variables at the provincial level

\begin{tabular}{lccccc}
\hline \multicolumn{1}{c}{ Variable } & Obs & Mean & Std. Dev. & Min & Max \\
\hline \hline Congestion declarative & 700 & 1,641 & 0,190 & 1,269 & 2,402 \\
Congestion execution & 700 & 4,175 & 1,210 & 1,828 & 10,089 \\
Congestion administrative & 700 & 1,826 & 0,417 & 0,916 & 3,613 \\
total populaiton & 700 & 897.459 & 1.103 .439 & 90.503 & 6.425 .901 \\
population growth & 700 & 0,007 & 0,013 & $-0,014$ & 0,058 \\
GDP per capita & 700 & 20.723 & 4.592 & 11.516 & 37.675 \\
total GDP growth rate & 700 & 0,031 & 0,046 & $-0,102$ & 0,150 \\
credit to GDP ratio & 700 & 0,532 & 0,217 & 0,205 & 1,681 \\
lawyers to population ratio & 700 & 0,000 & 0,000 & 0,000 & 0,001 \\
\hline
\end{tabular}

Note: In the analysis all variables are lagged by one year. The period of analysis is 2003-2016 (which is common across all measures of congestion rate). Summary statistics are computed over the period 2002-2015, which is the time variation exploited in the analysis.

Source: Own elaboration. 


\title{
BANCO DE ESPAÑA PUBLICATIONS
}

\author{
WORKING PAPERS
}

1830 JACOPO TIMINI and MARINA CONESA: Chinese exports and non-tariff measures: testing for heterogeneous effects at the product level.

1831 JAVIER ANDRÉS, JOSÉ E. BOSCÁ, JAVIER FERRI and CRISTINA FUENTES-ALBERO: Households' balance sheets and the effect of fiscal policy.

1832 ÓSCAR ARCE, MIGUEL GARCÍA-POSADA, SERGIO MAYORDOMO and STEVEN ONGENA: Adapting lending policies when negative interest rates hit banks' profits.

1833 VICENTE SALAS, LUCIO SAN JUAN and JAVIER VALLÉS: Corporate cost and profit shares in the euro area and the US: the same story?

1834 MARTÍN GONZÁLEZ-EIRAS and CARLOS SANZ: Women's representation in politics: voter bias, party bias, and electoral systems.

1835 MÓNICA CORREA-LÓPEZ and BEATRIZ DE BLAS: Faraway, so close! Technology diffusion and firm heterogeneity in the medium term cycle of advanced economies.

1836 JACOPO TIMINI: The margins of trade: market entry and sector spillovers, the case of Italy (1862-1913).

1837 HENRIQUE S. BASSO and OMAR RACHEDI: The young, the old, and the government: demographics and fiscal multipliers.

1838 PAU ROLDÁN and SONIA GILBUKH: Firm dynamics and pricing under customer capital accumulation.

1839 GUILHERME BANDEIRA, JORDI CABALLÉ and EUGENIA VELLA: Should I stay or should I go? Austerity, unemployment and migration.

1840 ALESSIO MORO and OMAR RACHEDI: The changing structure of government consumption spending.

1841 GERGELY GANICS, ATSUSHI INOUE and BARBARA ROSSI: Confidence intervals for bias and size distortion in IV and local projections - IV models.

1842 MARÍA GIL, JAVIER J. PÉREZ, A. JESÚS SÁNCHEZ and ALBERTO URTASUN: Nowcasting private consumption: traditional indicators, uncertainty measures, credit cards and some internet data.

1843 MATÍAS LAMAS and JAVIER MENCÍA: What drives sovereign debt portfolios of banks in a crisis context?

1844 MIGUEL ALMUNIA, POL ANTRÀS, DAVID LÓPEZ-RODRÍGUEZ and EDUARDO MORALES: Venting out: exports during a domestic slump.

1845 LUCA FORNARO and FEDERICA ROMEI: The paradox of global thrift.

1846 JUAN S. MORA-SANGUINETTI and MARTA MARTÍNEZ-MATUTE: An economic analysis of court fees: evidence from the Spanish civil jurisdiction.

1847 MIKEL BEDAYO, ÁNGEL ESTRADA and JESÚS SAURINA: Bank capital, lending booms, and busts. Evidence from Spain in the last 150 years.

1848 DANIEL DEJUÁN and CORINNA GHIRELLI: Policy uncertainty and investment in Spain.

1849 CRISTINA BARCELÓ and ERNESTO VILLANUEVA: The risk of job loss, household formation and housing demand: evidence from differences in severance payments.

1850 FEDERICO TAGLIATI: Welfare effects of an in-kind transfer program: evidence from Mexico.

1851 ÓSCAR ARCE, GALO NUÑO, DOMINIK THALER and CARLOS THOMAS: A large central bank balance sheet? Floor vs corridor systems in a New Keynesian environment.

1901 EDUARDO GUTIÉRREZ and ENRIQUE MORAL-BENITO: Trade and credit: revisiting the evidence.

1902 LAURENT CAVENAILE and PAU ROLDAN: Advertising, innovation and economic growth.

1903 DESISLAVA C. ANDREEVA and MIGUEL GARCÍA-POSADA: The impact of the ECB's targeted long-term refinancing operations on banks' lending policies: the role of competition.

1904 ANDREA ALBANESE, CORINNA GHIRELLI and MATTEO PICCHIO: Timed to say goodbye: does unemployment benefit eligibility affect worker layoffs?

1905 CORINNA GHIRELLI, MARÍA GIL, JAVIER J. PÉREZ and ALBERTO URTASUN: Measuring economic and economic policy uncertainty, and their macroeconomic effects: the case of Spain.

1906 CORINNA GHIRELLI, JAVIER J. PÉREZ and ALBERTO URTASUN: A new economic policy uncertainty index for Spain.

1907 ESTEBAN GARCÍA-MIRALLES, NEZIH GUNER and ROBERTO RAMOS: The Spanish personal income tax: facts and parametric estimates.

1908 SERGIO MAYORDOMO and OMAR RACHEDI: The China syndrome affects banks: the credit supply channel of foreign import competition. 
1909 MÓNICA CORREA-LÓPEZ, MATÍAS PACCE and KATHI SCHLEPPER: Exploring trend inflation dynamics in Euro Area countries.

1910 JAMES COSTAIN, ANTON NAKOV and BORJA PETIT: Monetary policy implications of state-dependent prices and wages.

1911 JAMES CLOYNE, CLODOMIRO FERREIRA, MAREN FROEMEL and PAOLO SURICO: Monetary policy, corporate finance and investment.

1912 CHRISTIAN CASTRO and JORGE E. GALÁN: Drivers of productivity in the Spanish banking sector: recent evidence.

1913 SUSANA PÁRRAGA RODRÍGUEZ: The effects of pension-related policies on household spending.

1914 MÁXIMO CAMACHO, MARÍA DOLORES GADEA and ANA GÓMEZ LOSCOS: A new approach to dating the reference cycle.

1915 LAURA HOSPIDO, LUC LAEVEN and ANA LAMO: The gender promotion gap: evidence from Central Banking.

1916 PABLO AGUILAR, STEPHAN FAHR, EDDIE GERBA and SAMUEL HURTADO: Quest for robust optimal macroprudential policy.

1917 CARMEN BROTO and MATÍAS LAMAS: Is market liquidity less resilient after the financial crisis? Evidence for US treasuries.

1918 LAURA HOSPIDO and CARLOS SANZ: Gender Gaps in the Evaluation of Research: Evidence from Submissions to Economics Conferences.

1919 SAKI BIGIO, GALO NUÑO and JUAN PASSADORE: A framework for debt-maturity management.

1920 LUIS J. ÁLVAREZ, MARÍA DOLORES GADEA and ANA GÓMEZ-LOSCOS: Inflation interdependence in advanced economies.

1921 DIEGO BODAS, JUAN R. GARCÍA LÓPEZ, JUAN MURILLO ARIAS, MATÍAS J. PACCE, TOMASA RODRIGO LÓPEZ, JUAN DE DIOS ROMERO PALOP, PEP RUIZ DE AGUIRRE, CAMILO A. ULLOA and HERIBERT VALERO LAPAZ: Measuring retail trade using card transactional data.

1922 MARIO ALLOZA and CARLOS SANZ: Jobs multipliers: evidence from a large fiscal stimulus in Spain.

1923 KATARZYNA BUDNIK, MASSIMILIANO AFFINITO, GAIA BARBIC, SAIFFEDINE BEN HADJ, ÉDOUARD CHRÉTIEN, HANS DEWACHTER, CLARA ISABEL GONZÁLEZ, JENNY HU, LAURI JANTUNEN, RAMONA JIMBOREAN, OTSO MANNINEN, RICARDO MARTINHO, JAVIER MENCÍA, ELENA MOUSARRI, LAURYNAS NARUŠEVIČIUS, GIULIO NICOLETTI, MICHAEL O'GRADY, SELCUK OZSAHIN, ANA REGINA PEREIRA, JAIRO RIVERA-ROZO, CONSTANTINOS TRIKOUPIS, FABRIZIO VENDITTI and SOFÍA VELASCO: The benefits and costs of adjusting bank capitalisation: evidence from Euro Area countries.

1924 MIGUEL ALMUNIA and DAVID LÓPEZ-RODRÍGUEZ: The elasticity of taxable income in Spain: 1999-2014.

1925 DANILO LEIVA-LEON and LORENZO DUCTOR: Fluctuations in global macro volatility.

1926 JEF BOECKX, MAARTEN DOSSCHE, ALESSANDRO GALESI, BORIS HOFMANN and GERT PEERSMAN: Do SVARs with sign restrictions not identify unconventional monetary policy shocks?

1927 DANIEL DEJUÁN and JUAN S. MORA-SANGUINETTI: Quality of enforcement and investment decisions. Firm-level evidence from Spain.

BANCODEESPAÑA Eurosistema
Unidad de Servicios Auxiliares

Alcalá, 48 - 28014 Madrid

E-mail: publicaciones@bde.es www.bde.es 